\title{
Mislava Bertoša
}

Tvrtko Vuković

(Filozofski fakultet Sveučilišta u Zagrebu)

\section{LOV NA DEGENERIKE \\ Psihijatrija i normalizacija hrvatskog građanskog društva na primjeru slučaja Miloša Krpana}

UDK 616.89(497.5)(091)

329 Krpan, M.

Izvorni znanstveni rad

Primljeno: 11. 1. 2020.

Polazeći od psihijatrijskog slučaja Miloša Krpana, jednog od naših prvih socijalista i anarhista, koji je koncem 19. stoljeća dva puta primljen u Kraljevski zemaljski zavod za umobolne u Stenjevcu, radom se pokušava pokazati kako onodobna psihijatrija, sudjelujući u procesu oblikovanja hrvatskog građanskog društva, osim medicinskog znanja, razvija i normalizacijsku moć. Psihijatrija pacificira otpor sustavu tako što ga izmješta u Zavod te ga ondje ispituje, obrađuje, svladava i disciplinira. Istodobno sebi pribavlja znanstveni legitimitet i stječe društveni status proizvodeći kategoriju nenormalnosti te razvijajući tehnike za njezino suzbijanje. Tako preuzima odgovornost za ćudoređe, sigurnost i čistoću društva, a povezujući se sa sudskom praksom postaje nositelj pravne moći. Drugim riječima, osim što nastoji liječiti ludilo, psihijatrija se javlja kao stroj društvene discipline uspostavljajući moderne oblike normalizacijske moći u mladom buržoazijskom kapitalističkom društvu druge polovice 19. stoljeća.

Ključne riječi: povijest psihijatrije, nenormalnost, normalizacija, degeneracija, Miloš Krpan

Medicinska moć nad nepatološkim, to je, vjerujem, središnji problem (...) psihijatrije. (...) Psihijatrija više ne zahtijeva, ili esencijalno više ne zahtijeva, da liječi. Ona može ponuditi (...) da funkcionira naprosto kao zaštita od nepopravljivo opasnih, ljudi nenormalnog stanja, čijom žrtvom društvo može postati. Medikalizacijom nenormalnog (...) psihijatrija će moći tražiti upravo funkciju koja će naprosto biti funkcija zaštite i reda. (...) Ona može djelotvorno (i baš to čini na koncu XIX. stoljeća) tvrditi da zamjenjuje sâmo pravo, i ne samo 
pravo nego i higijenu, i ne samo higijenu nego u konačnici i najveći dio društvenih posredovanja i kontrola, tako da postaje općim mjestom obrane društva od opasnosti koje ga potkopavaju iznutra. (...) Je li osoba opasna? Može li se optuženika kazniti? Je li optuženik izlječiv? To su pitanja bez važnosti za pravo, pitanja koja nemaju veću važnost za onu psihijatriju koja se doista usredotočila na bolest; međutim, to su pitanja koja u potpunosti imaju određeno značenje $\mathrm{u}$ trenutku kada su bila postavljena psihijatriji koja u osnovi funkcionira kao obrana društva ili, prizivajući termine XIX. stoljeća, koja funkcionira kao lov na degenerike. Degenerik je onaj koji je opasan. Degenerik je onaj kome se ni jedna kazna ne može odrediti. Degenerik je onaj koji u svakom smislu ostaje neizlječiv. Ta tri pitanja, bez medicinskog značenja, bez patologijskog značenja, bez pravnog značenja imaju, $s$ druge stane, posve određeno značenje u medicini nenormalnog koja nije medicina patološkog ili bolesti; u medicini koja shodno tome nastavlja biti, u osnovi, psihijatrija degeneriranih. ${ }^{1}$

\section{Od anarhije do paranoje: slučaj Miloša Krpana}

Bio je utorak 7. prosinca 1897. U Kraljevski zemaljski zavod za umobolne u Stenjevcu ${ }^{2}$ primljen je pacijent Miloš Krpan. Zaveden je pod matičnim brojem 3314, a u Bilježkama o bolesti stoji da je došao u pratnji redarstvenog agenta Gjure Jozića. ${ }^{3}$ Krpan je naime prije hospitalizacije, od 20. ožujka do 14. travnja, proveo u "uzah Kr. rat. suda u Brodu", ${ }^{4}$ a potom nešto manje od osam mjeseci u istražnome zatvoru "kod Sudbenoga stola u Zagrebu". Razlog uhićenja bili su inkriminirajući spisi pronađeni prilikom premetačine njegove kuće u selu Duboviku. ${ }^{6}$ Krpanov stenjevečki dosje vrlo je detaljan, stoga se iz njega može razabrati kako je do premetačine došlo. U ožujku je 1897.

${ }^{1}$ Michel Foucault, Les anormaux (Paris: Gallimard-Le seuil, 1999), 292-300.

${ }^{2}$ Zavod je pušten u rad 1879. O njegovu otvorenju nema zabilješki. Prvi ravnatelj dr. Ivan Rohaček na radno je mjesto stupio 1. listopada 1879. Prije toga obavljao je posao kućnog liječnika u kaznionici u Lepoglavi. Usp. Rudolf Herceg, "Zavod za umobolne 'Stenjevec' od 1879. do 1933”, u: Stenjevec, državna bolnica za duševne bolesti 1879-1933 (Zagreb: Društvo za socijalnu pomoć duševnim bolesnicima u Stenjevcu, 1933), 6-29.

${ }^{3}$ Ako se drukčije ne navede, svi citati koji se odnose na boravak Miloša Krpana u Kraljevskom zemaljskom zavodu za umobolne u Stenjevcu doneseni su iz njegova dosjea pohranjenog u Arhivu Klinike za psihijatriju "Vrapče". Navodi iz Krpanova dosjea u tekstu će biti označeni kraticom AKPV: MK.

${ }^{4}$ AKPV: MK. Brod ili Posavski Brod današnji je Slavonski Brod.

${ }^{5}$ D. Dedić kao datum Krpanova uhićenja navodi travanj, no iz njegova dosjea, točnije iz priložene Liečničke svjedočbe i dopisa Odjela za bogoštovlje i nastavu, očito je da je uhićen u ožujku 1897. AKPV: MK.

${ }^{6}$ Selo Dubovik nalazi se sjeverno od Slavonskog Broda u podnožju gore Dilj. Nakon što je u Petrinji završio učiteljsku školu, Krpan se 1883. doseljava u Dubovik, gdje preuzima mjesto seoskog učitelja. Rođen je 27. srpnja 1862. u selu Lipe kod Gospića. U našoj historiografiji posebnu pažnju izaziva njegov građanski aktivizam i političko djelovanje koje je bilo u do- 
"porobljena blagajna Kostajničke štedionice te je taj zločin socijalistima u grieh upisan te pošto je kod jednoga socijaliste osumnjičenog radi te kradje nadjeno pismo od Krpana, to je bila naložena premetačina u njegovu stanu. Tom prigodom nadjena je medju starima papirima na tavanu satirička od Krpana složena pjesma (Sirotinjska pjesma) koja je sadržavala porugljive stihove o raskalašenima priležnicima carice Marije Terezije, nadalje o nepotrebnosti militarizma, nadalje kako bi narod sveobćim glasovanjem imao odlučivati o svojim potrebama i birati nosioca državne vlasti. Nadalje slavi u toj pjesmi socijalizam i anarhizam"7

Krpanovo političko djelovanje, koje je on sam definirao kao komunistički anarhizam, ${ }^{8}$ započinje u vrijeme režima Khuena Héderváryja i ubrzo postaje predmetom interesa represivnih organa vlasti. ${ }^{9}$ Njegov je rad u zajednici nesumnjivo bio raznovrstan i vrlo plodan. Osim pisanja članaka o društvenoj nepravdi i političkoj korumpiranosti, obuhvaćao je poticanje udruživanja radnika, seljaka i obrtnika te organiziranje prosvjeda, javnih skupova i štrajkova. Krpanov je socijalni aktivizam uključivao održavanje izravnih kontakata i uspostavljanje korespondencije s istaknutim domaćim socijalistima, ali i inozemnim anarhistima. Nagađa se također da je stupio u vezu i s nekolicinom vodećih mislilaca

\footnotetext{
sluhu s idejama anarhizma, socijalizma i komunizma. Djelujući mahom u okolici Slavonskog Broda, a katkad i drugdje na području Slavonije, život je posvetio borbi za radnička i građanska prava. Usp. Dejan Dedić, "Prilog biografiji Miloša Krpana", u: Miloš Krpan. Izabrani spisi, ur. Dejan Dedić (Zagreb: DAF, 2010), 247-255.
}

${ }^{7}$ AKPV: MK.

${ }^{8}$ Recenzentima zahvaljujemo na upozorenju o složenoj naravi Krpanova političkog djelovanja. Osvrćući se na njegov tekst iz 1894. o teškom ekonomskom položaju slavonskih šumskih radnika, Pejić napominje da je Krpan "etablirani pučki tribun, govornik te kasnije samoproglašeni anarhist brodskog kraja". Usp. Luka Pejić, "Godine revolta: Štrajkovi radnika slavonske drvnoprerađivačke industrije (1905. - 1907.)", u: Slavonske šume kroz povijest. Zbornik radova znanstvenog skupa s međunarodnim sudjelovanjem održanog u Slavonskom Brodu 1.-2. listopada 2015., ur. Dinko Župan i Robert Skenderović (Slavonski Brod: Hrvatski institut za povijest - Podružnica za povijest Slavonije, Srijema i Baranje, 2018), 329. Prikazujući Krpanovu ulogu u događajima oko štrajkova radnika slavonske drvnoprerađivačke industrije od 1905. do 1907, Pejić daje pregled njegova nimalo jednosmjernog i jednoznačnog političkog angažmana, koji se kreće od privrženosti socijalističkim idejama, preko kritike Socijademokratske stranke Hrvatske i Slavonije, do prihvaćanja anarhističkih stavova. O Krpanovu anarhizmu usp. Ana Rajković, "Počeci kreiranja anarhističkog narativa u kontekstu slavonskog radničkog pokreta (1881-1914)", Historijski zbornik 1 (2018): 61-86. Usp. također Krpanov proglas o osnivanju anarhističko-komunističke kolonije upućen bečkoj grupi anarhista, a objavljen je u bečkom anarhističkom časopisu Wohlstand für Alle 18. srpnja 1909. u rubrici Dopisivanje. O tome Dedić, "Prilog biografiji Miloša Krpana", 247-255. Također i: Ivan Kovačević, "Pokušaj osnivanja anarhističko-komunističke kolonije u Duboviku kraj Slavonskog Broda (1909. i 1910.)", u: Miloš Krpan. Izabrani spisi, ur. Dejan Dedić (Zagreb: DAF, 2010), 243.

9 Dedić, "Prilog biografiji Miloša Krpana”, 248. 
onoga vremena, poput Pasteura, Tesle, Engelsa i Edisona. ${ }^{10}$ Drugim riječima, onodobnom društvenom poretku Krpan je u svakom pogledu bio izravna prijetnja. Njegovo je uhićenje 1897. u neposrednoj vezi s Khuenovim progonom socijalista i pokušajem režima da oslabi ili posvema uništi radnički pokret. ${ }^{11}$ Proces protiv Krpana vođen je u tajnosti, da bi "nakon gotovo osam mjeseci zadržavanja u pritvoru (...) bila podignuta optužnica za 'zločinstvo pokušanog zavođenja na veleizdaju (§. 9. i 59. k. z.), na zločinstvo uvriede članova cesarske i kraljevske kuće (§. 64.), zločinstvo smetanja javnog mira (§. 65.) te zločinstvo smetanja vjerozakona (§. 122.)."' ${ }^{12}$ Osim toga, a na temelju dopisa "Kraljevskog državnog odvjetničva" od 12. listopada 1897, razvidno je da su se Krpanu pripisivali i zločini po članku 58. kaznenog zakona (zločinstvo veleizdaje), po članku 303. (vriedjanje crkve ili družbe vjerozakonske), 302. (draženje na neprijateljstva proti narodnosnim, proti družbama vierozakonskim) te na koncu 305. (javno ponizivanje uredbah, odnosećih na ženitbu, na obitelj, na vlastničtvo, ili odobravanje činah nezakonitih ili nećudorednih). ${ }^{13}$

Smatra se da je Krpan naposljetku "oslobođen optužbi i iz pritvora upućen na promatranje u Kraljevski zemaljski zavod za umobolne u Stenjevcu jer se njegov branitelj, dr. Josip Frank, pozvao na Krpanovu neubrojivost". ${ }^{14}$ Slučaj je ipak nešto složeniji. Iz dosjea se može iščitati da je Krpan u Zavodu bio dvaput. Prvi put je ondje boravio od 7. prosinca 1897. do 20. siječnja 1898., kada je "poboljšan suprugi predan na revers" s dijagnozom "paranoia originaria". ${ }^{15}$ Iz Liečničke svjedočbe napisane u Zagrebu 5. prosinca 1897. ja-

${ }^{10}$ Usp. Miljenko Predragović, "Da li se naš Miloš Krpan dopisivao s Engelsom?”, Vjesnik (Zagreb), 11. lipnja 1972; Kovačević, "Pokušaj osnivanja anarhističko-komunističke kolonije", 240; AKPV: MK.

${ }^{11}$ L. Pejić napominje da je nakon zaključaka Druge Internacionale o potrebi uključivanja seoskog proletarijata u socijalistički pokret u brojnim slavonskim i srijemskim selima došlo do pobune seljaštva. 1897. bila je burna izborna godina tijekom koje su ojačale socijaldemokratske aktivnosti u Slavoniji. "Ilegalno djelujući, prije svega u pogledu dijeljenja subverzivnih tiskovina te održavanja radničkih skupština, socijaldemokrati su sve do 1897. intenzivirali svoje djelovanje na selu, potaknuvši nekoliko pobuna koje su rezultirale uhićenjima i sudskim procesima protiv seljaštva u okolici Osijeka.” Krpanovo uhićenje i smještanje u Zavod povezani su s tim događanjima. Usp. Luka Pejić, "Odnos radničkog pokreta i seljaštva na prijelazu iz 19. u 20. stoljeće u Osijeku i okolici“, Historijski zbornik LXX (2017), 2: 434.

${ }^{12}$ Dedić, "Prilog biografiji Miloša Krpana”, 249.

${ }^{13}$ AKPV: MK. Zločini koji su se Krpanu pripisivali spadali su u red teških kaznenih djela i mogli su biti kažnjeni vrlo dugotrajnim zatvorskim kaznama, a u određenim slučajevima i izvršenjem smrtne presude. Usp. Josip Šilović (ur.), Kazneni zakon o zločinstvih, prestupcih i prekršajih od 27. svibnja 1852. sa zakoni i naredbami i sa rješidbami. Zakon o porabi tiska od 17. svibnja 1875., izpravljen prema zakonu od 14. svibnja 1907. o promjeni tiskovnih zakona (Zagreb: St. Kugli, Knjižara Kraljevskog Sveučilišta i Jugoslavenske akademije, 1908).

${ }^{14}$ Dedić, "Prilog biografiji Miloša Krpana", 249.

${ }^{15}$ AKPV: MK. 
sno je da je po nalogu glavnog gradskog "poglavarstva kao redarstvene oblasti u Zagrebu" Krpana pregledao "gradski fizik" dr. Švrljuga. Dr. Švrljuga najprije prenosi da su sudbeni vještaci prof. Lahmayer i dr. Schliek na ročištu u srpnju utvrdili kako je Krpan "svojih riječi i djela svjestan, dakle da je ubrojiv i za svoje riječi i djela odgovoran, nu da se je u njega razvila neka vrst megalomanije, koja je često preteča ozbiljne duševne bolesti”. U nastavku piše da je na konačnoj raspravi dana 24. studenog sudski vještak dr. Schliek izjavio "da je Krpan u vrieme počinjenja kažnjivih djela bio u takvoj moći ćuta da mu se imputirana djela ne mogu ubrojiti" pa je na temelju toga "radi očevidne duševne smetenosti od optužbe riešen". ${ }^{16}$ Nakon toga 26. studenog Kraljevski sudbeni stol u Zagrebu predaje Krpana Gradskom poglavarstvu u Zagrebu s opaskom da je "on osoba javnoj sigurnosti pogibeljna". Zapisniku je priložena molba kojom Krpan na temelju izvještaja sudskog vještaka dr. Schlieka i na temelju toga što "u sebi osjeća njeku nervoznost; - [traži] da se smjesti na liečenje u Kr. zem. zavod za umobolne". Pregledavši kratko Krpana, dr. Švrljuga je utvrdio da je "isti tjelesno iznemogao i moralno shrvan" pa je zaključio kako nije u stanju donijeti "stalan sud o njegovom duševnom stanju". No, nastavlja kako Krpanu ipak treba "psihijatričke liečničke njege, pa da je prikladan objekt liečenja u Kr. zem. zavodu za umobolne u Stenjevcu, stoga molim da se u rečeni zavod privede". ${ }^{17}$

Bjelodano je da je Krpan u Zavod prvi put dospio tako što je, potaknut uvidom sudskog vještaka dr. Schlieka, to na određeni način sam tražio. Iz navedenoga se međutim lako može razabrati da su sudbena vlast i represivni aparat $\mathrm{u}$ jednom trenutku dio svojih ingerencija prenijeli na psihijatriju. $\mathrm{Bu}-$ dući da je Krpan osoba “javnoj sigurnosti pogibeljna”, a iz nekog razloga ga nije bilo moguće osuditi i zatočiti, psihijatrija za njega preuzima odgovornost. Izravnu represiju i isključivanje pojedinca iz društva tako smjenjuje njegovo uključivanje u rad institucije koja, povezujući disciplinarnu moć i medicinsko znanje, društvo naprosto nastoji obraniti od pogibelji. Uloga je psihijatrije tu prije svega odlučiti je li Krpan opasan za druge i zajednicu u cjelini. Njegovu juridičku diskvalifikaciju kao subjekta prava "djelomično popunjava i djelomično zamjenjuje niz [psihijatrijskih] tehnika i praksi za dresuru onih koji se dresuri opiru i za popravljanje nepopravljivih". ${ }^{18}$ Valja pritom istaknuti još nekoliko stvari. Na temelju vrlo površnog uvida u Krpanovo mentalno zdravlje, dakle bez ikakve mogućnosti utvrđivanja precizne dijagnoze, sudski vještaci donose zaključak u kojemu koriste psihijatrijske termine (megalomanija). Sam Krpan, premda kasnije u jednom pismu nekom stožerniku tvrdi da je nepreslušan lukavštinom dospio u ludnicu, u svojoj molbi kao razlog za hospitalizaciju

\footnotetext{
${ }^{16}$ Isto.

${ }^{17}$ Isto.

${ }^{18}$ Michel Foucault, Les anormaux (Paris: Gallimard-Le seuil, 1999), 308.
} 
navodi i "njeku nervoznost", vrlo vjerojatno želeći aludirati na neurasteniju. ${ }^{19}$ Iako nije mogao donijeti konačno mišljenje o stanju Krpanova duha, "gradski fizik" dr. Švrljuga Liečničku svjedočbu zaključuje tvrdnjom da je ovaj ipak "prikladan obijekt liečenja u Kr. zem. zavodu za umobolne u Stenjevcu". ${ }^{20}$ Jezik psihijatrije oduzeo je prednost jeziku prava, a njegova snaga nedvojbeno ne izbija iz znanstvene istine iskaza, nego iz gotovo šamanskog plesa termina. Razvidno je da psihijatrijska moć ne potječe iz "sadržaja znanja, nego iz formalno zakonski ovjerenog znanja. Drugim riječima, simbolima što ukazuju na posjedovanje znanja, i samo djelovanjem tih simbola, neovisno o tome što je trenutni sadržaj toga znanja", ${ }^{21}$ psihijatrija stječe mogućnost ovladavanja neposlušnim tijelima, opasnim pojedincima i uopće nenormalnim pojavama.

Sudbena vlast ovdje očito nastoji izbjeći izricanje surove kazne, a iskazi vještaka, psihijatara, pa i samog optuženika, omogućuju jedan drugi tip kažnjavanja, točnije postupanja, koji nije povezan sa samim činom kaznenog djela, nego ponajprije s psihom i moralom privedene osobe. Tu "psihijatrijsko stručno mišljenje omogućuje da točka primjene kazne za prekršaj definiran zakonom prijeđe u kaznenu odgovornost prosuđivanu iz psihološko-moralne točke gledišta. (...) Njegova je osnovna uloga da u formi znanstvenoga znanja ozakoni proširenje kaznene moći na nešto drugo doli kazneno djelo". ${ }^{22} \mathrm{U}$ Krpanovu slučaju vještačenja ukazuju na "zlodjela koja nisu kaznena djela (...), nepravilnosti koje nisu nezakonite". Namjera im je pokazati kako "pojedinac već nalikuje svojemu zločinu prije negoli ga je počinio". ${ }^{23}$ Bez dvojbe, tu moć izravnog kažnjavanja uzmiče ne bi li se oslobodilo mjesto tehnikama prilagodbe i transformacije osuđenika. Te tehnike, oblikovane i stavljene u upotrebu velikim dijelom i psihijatrijskom moći, neodvojive su od proizvodnje figure delinkventa i degenerika u 19. stoljeću. Krpanova sudbina očit je primjer. Sudski vještaci, liječnici, profesori, psihijatri omogućuju da se posve odbaci uloga počinitelja zločina, ne bi li na scenu stupila nenormalna osoba čiji su prijestupi ponajprije posljedica moralne i psihološke neuravnoteženosti

${ }^{19}$ Termin neurastenija izumio je njujorški liječnik George Miller Beard 60-ih 19. stoljeća. Termin je pokrivao sve oblike i tipove nervne iscrpljenosti povezane s mozgom i leđnom moždinom. Krajem 19. stoljeća bolest se povezivala sa zamorom koji brz razvoj suvremene civilizacije donosi sa sobom crpeći čovjekovu intelektualnu i tjelesnu energiju. Usp. Simon Wessely, "Neurastenija and Fatigue Syndromes", u: A History of Clinical Psychiatry, ur. German E. Berrios, Roy Porter (London: The Altone Press, 1995), 509-532. Također: Anson Rabinbach, "Mental Fatigue, Neurastenia, and Civilization", u: Human Motor: Energy, Fatigue, and the Origins of Modernity (Berkley-Los Angeles: University of California Press, 1992), 146-178.

${ }^{20}$ AKPV: MK.

${ }^{21}$ Michel Foucault, Psychiatric Power (New York: Palgrave Macmillian, 2006), 184.

${ }^{22}$ Foucault, Les anormaux, 17-18.

${ }^{23}$ Isto. 
uzrokovane patološkim nasljeđem te poremećajima u ranom razvoju i tijekom odrastanja. U Krpanovoj povijesti bolesti maglovita obiteljska anamneza i površna rekonstrukcija navika iz djetinjstva nesumnjivo su bili prevladavajući dijagnostički alat. Tu je posve jasno da "djetinjstvo postaje ključni element u novom načinu funkcioniranja psihijatrije", a "pripisivanje izvora nenormalnog stanja hereditarnosti" ${ }^{24}$ jedan od vidova medikalizacije društveno opasnih pojava koje nije moguće izravno kazniti. U tom pogledu nije bio važan čin koji je Krpan zločinom počinio, nego njegovo mentalno stanje. Od objekta represivnog aparata, on postaje objekt normalizacije.

U okviru kaznenog sustava Krpan nije promatran kao zločinac ili prekršitelj. On je rođeni delinkvent, društveno opasan pojedinac, čiji zločini proistječu iz njegova života, karaktera, podrijetla i psihe. Zbog toga namjera sustava nije bila kazniti ga, nego popraviti i njime djelotvornije manipulirati. Da bi ga se preodgojilo, potrebno je bilo njegov posve iščašeni nagon uravnotežiti. Krpana anarhista istražni zatvor prevodi u prijestupnika "kao patologizirani subjekt". ${ }^{25}$ Bezakonje nije tek isključeno iz društva, nego je u njega vraćeno u vidu nenormalnosti koja se potom medikalizira da bi se nadzirala i na koncu normirala. Uloga psihijatrijskih vještaka u tom je smislu posve jasna: njima je bilo moguće na temelju izuma povezanosti medicine i kriminalistike razlučiti kaznu od terapije te delinkventa prevesti u degenerika. Delinkvent i degenerik izravna su prijetnja zdravlju buržoaskog života, a medicinsko-pravni diskurs, uobličen u drugoj polovici 19. stoljeća, zapravo je odgovor na tu socijalnu opasnost. Krpanov slučaj pruža dobar uvid u te procese: zločinac postaje nenormalna osoba te predmet medicinsko-pravnog diskursa i objekt psihijatrijske moći u okviru potrebe buržoaskog kapitalističkog društva da pojedincima učinkovitije upravlja, lakše ih nadzire, normira im mjesta i uloge te odredi isplativije modele njihova djelovanja.

Prvi Krpanov boravak u Zavodu bio je razmjerno kratak, a dio dosjea koji se odnosi na to vrijeme obuhvaća tri stranice ispisane nešto teže čitljivim rukopisom te osam stranica mišljenja koje je, po svemu se čini, naknadna rekonstrukcija ${ }^{26} \mathrm{Ta}$ je inačica poslužila i sastavljanju "Liečničkog mnienja o duševnom stanju istraženika Miloša Krpana podano na zahtjev Kr. sudb. stola

${ }^{24}$ Isto, 286, 296.

${ }^{25}$ Michel Foucault, Nadzor i kazna, (Zagreb: Informator-Fakultet političkih znanosti, 1994), 289.

${ }^{26}$ Zaključak je izveden na temelju ovih činjenica: rekonstrukcija je rađena na istoj vrsti papira na kojoj su napisane prve Krpanove Bilježke o bolesti; neki dijelovi tih nečitko pisanih izvornih bilježaka sadržajno odgovaraju tekstu rekonstrukcije; u rekonstrukciji se prenosi Krpanov navod u kojem on spominje datum 7. XII. 1897. kao datum kada je dobrovoljno odlučio doći u Zavod; na dva mjesta na listovima na kojima je napisano liječničko mišljenje pojavljuje se datum 23. 2. 1898, a na jednom mjestu taj je datum povezan s nalogom suda od 19. 2. 1898. da se izda izvještaj o Krpanovu mentalnom zdravlju. 
u Požegi od 15. prosinca 1898. br. 8517. Kz" ${ }^{27}$ Naime, nakon što je Krpan iznova uhićen, ovo je liječničko mišljenje tražio državni odvjetnik. Razlog tome je taj što je Krpanov branitelj “dr. Josip Frank zamolio da se glavna rasprava odgodi u svrhu konstatiranja duševnog stanja istraženika jer je isti dne 24. XI. '97. presudom Kr. sudb. stola u Zagrebu radi duševne smetenosti riešen obtužbe poradi zločinstva veleizdaje i uvrede članova carske kuće $i$ smetanja javnog mira i smetanja vjerozakona". ${ }^{28}$ Ta je molba dakle bila povodom drugog Krpanova boravka u Zavodu, dok je molbu za prvi boravak, kako je već rečeno, pisao sam Krpan na temelju nalaza dr. Schlieka. Dedić napominje da je između prvog i drugog boravka u Zavodu Krpan bio izvrgnut novim progonima, pa se zbog toga uz pomoć austrijske socijaldemokratske stranke sklanja najprije u Beč, a potom u Zürcih. "U Dubovik se vraća krajem 1898. i ponovno biva uhićen ovaj put pod optužbom da je počinio 'zločinstvo smetanja vjerozakona $\S .122$ "”. ${ }^{29}$

Selektivno i ne posve precizno čitanje dosjea navodi na zaključak da je Krpan iz Zavoda prvi put otpušten s pozitivnim liječničkim mnijenjem. "Nakon približno dva mjeseca promatranja Krpan je pušten u veljači 1898. tj. 'suprugi predan na revers' jer kao 'sasvim miran i nepogibljen čovjek pod nadzorom svoje supruge ili skrbnika mirno kod svoje kuće živiti može". ${ }^{30}$ Međutim, čini se kako je Krpanova sudbina bila nešto drukčija. Naime, može se nedvosmisleno utvrditi da je Krpan otpušten tek "poboljšan", da mu je postavljena dijagnoza "paranoia originaria", a na kraju liječničkog mišljenja stoji: "Zaključujemo ovo izvješće s tim da ga od naše strane za daljnje vršenje službe učiteljske preporučiti ne možemo, pošto se njegova duševna bolest (paranoia) koja je sada lahke naravi može tekom vremena pogoršati, ali nikad izliječiti" ${ }^{31}$ Nakon prvog boravka u Zavodu, Krpanu je očito onemogućen povratak na posao učitelja. Iz nalaza pisanog povodom njegova drugog hospitaliziranja jasno je i to da je u Duboviku bio 11. travnja 1898., kada je između njega i novog učitelja Stjepana Vlašića došlo do svađe. Ta je svađa naknadno dovela do Krpanova privođenja i drugog smještanja u Zavod. Evo dijelova Opisa čina koji se nalazi u dosjeu:

"Pučki učitelj u Duboviku g. Vlašić i njegova supruga Ivka pripovjedaju (...) da je Miloš Krpan došao na drugi dan Uskrsa sa narodom u

\footnotetext{
${ }^{27}$ AKPV: MK.

${ }^{28}$ Isto.

${ }^{29}$ Dedić, "Prilog biografiji Miloša Krpana", 250. U dosjeu piše i ovo: "Kažnjivo po paragrafu 124. Kz" (AKPV: MK). U zakonu stoji: "kazni se tamnicom od šest miesecih do jedne godine danah". Usp. Šilović (ur.), Kazneni zakon o zločinstvih.

${ }^{30}$ Dedić, "Prilog biografiji Miloša Krpana", 250.

${ }^{31}$ AKPV: MK.
} 
školu da odveze stvari koje su mu tamo ostale za vreme dok je još sam kao učitelj služio, te da je počeo rušiti ogradu, klupe i stolove i nositi s tavana daske. Kad ga je učitelj Vlašić upitao da li to mora baš na drugi dan Uskrsa raditi, počeo je Krpan navodno psovati Boga i Uskrs, kazao je da je duša njegova i učiteljeva kao i pasja duša. (...) Miloš Krpan sam iskazuje (...) da je za vrieme njegovog istražnog zatvora g. 1897. novi učitelj Stjepan Vlašić pronašao da manjka 12 knjiga u školskoj knjižnici, te stoga nije htio dozvoliti stvari prije odvesti. Kada je bio Krpan obtužbe riešen, dolazio je Vlašiću i našao je sve manjkajuće knjige u školskoj knjižnici. Usprkos tomu odbijao je Vlašić uvjek Krpana pa je stoga posljednji konačno došao i silom i vikom svoje stvari odnašao. Da je pritom izustio psovke radi kojih je obtužen to iztraženik dosljedno niječe". ${ }^{32}$

To su dakle okolnosti koje su dovele do Krpanova drugog uhićenja i njegove druge hospitalizacije u Zavodu. Primljen je 19. prosinca 1898. i zaveden pod matičnim brojem 3745, a otpušten 5. travnja 1899. "poboljšan”, ali iznova s dijagnozom "paranoia originaria". Dio dosjea koji se odnosi na to razdoblje obuhvaća devetnaest rukopisom pisanih stranica liječničkog mišljenja. Konačno Mnienje sastavljeno je 21. ožujka 1899. na temelju promatranja i ispitivanja pacijenta, njegovih dopisa, spisa, pisama i kratke biografije napisane u Zavodu te podataka prikupljenih za vrijeme prvog Krpanova liječenja. Svoje mišljenje liječnici zaključuju time da proglašavaju

"Miloša Krpana umobolnim, da on boluje od chroničkog ludila skopčanog sa precjenjivanjem svoje osobe i mislima progonstva (Paranoia originaria et persecutoria), da je nadalje njegova bolest neizlječive naravi te da mu se zločin radi kojega se sada u iztrazi nalazi ubrojiti ne može. Što se tiče dalnjega njegovog života to mislimo da on može, pošto je sasvim miran i nepogibeljan čovjek, pod nadzorom svoje žene ili skrbnika mirno kod svoje kuće živiti" ${ }^{33}$

Opasan, neizlječiv i nekažnjiv; anarhist Krpan tijekom psihijatrijske procedure nestaje kako bi se ubrzo pojavio kao nenormalna osoba, degenerik. Njegov patološki nagon postaje predmetom medikalizacije, nadgledanja, normalizacije i konačno higijenizacije. Društveni život psihijatrija pročišćava od zagađenosti i utjecaja devijacije, a materijalnu odgovornost za subjekt koji je iskočio iz kruženja kapitala prebacuje na obitelj. Tu se da uočiti povezivanje nekoliko znakovitih procesa. Svojim prvim koracima psihijatrija u Hrvatskoj pacificira otpor sustavu tako što ga izmješta u Zavod te ga ondje ispituje, obrađuje, svladava i disciplinira. Istodobno sebi pribavlja znanstveni legitimi-

\footnotetext{
${ }^{32}$ Isto.

${ }^{33}$ Isto.
} 
tet i stječe društvenu moć proizvodeći kategoriju nenormalnosti te oblikujući tehnike za njezino suzbijanje. Također preuzima odgovornost za ćudoređe, sigurnost i čistoću društva, subjekt koji je izmaknuo kruženju kapitala zbrinjava tako da umanji štetu, a povezujući se sa sudskom praksom postaje nositeljem pravne moći. Drugim riječima, osim što nastoji liječiti ludilo, psihijatrija se javlja kao stroj društvene discipline čiji se rad pokreće i ustaljuje tako što "profitira na nenormalnosti, ilegalnosti i iregularnosti". ${ }^{34}$ Otvaranjem sezone lova na degenerike psihijatrija u Hrvatskoj utire svoj znanstveni i disciplinarni put, uspostavljajući u isti mah moderne oblike normalizacijske moći u

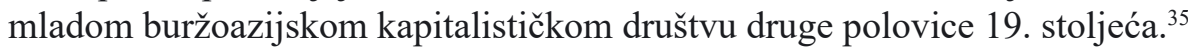

\section{„Mi smo napredak platili grdobom"36}

U drugoj polovici 19. stoljeća, u Europi nakon revolucija i političkih prevrata 1848, a na području hrvatskih zemalja nešto snažnije nakon Nagodbe 1868, dolazi do brojnih i u svakom smislu fundamentalnih društvenih promjena. Premda je ondašnja Trojedna Kraljevina bila većim dijelom ruralna zajednica, neusklađena s industrijskim, tehnološkim, znanstvenim i ekonomskim napretkom država Zapadne Europe, i ona se u doba kapitala (Hobsbawm), ${ }^{37}$ unatoč zaostalosti, nepovratno transformirala. Tijekom tranzicije iz feudalizma u kapitalizam, napose u tri zadnja desetljeća 19. i na početku 20. stoljeća, hrvatsko društvo obilježavaju brojni modernizacijski procesi. U industrijsku se proizvodnju uvode tehnološke inovacije, tržišno gospodarstvo uzima maha, ubrzava se transport, ali i svakodnevni život, ponude bankarskog sektora se proširuju, plasiraju se različiti modeli kreditiranja, komunikacije skraćuju vrijeme, broj publikacija se višestruko povećava, a pojavljuju se i novi vizualni te auditivni mediji, pravni mehanizmi i zakonodavni okviri se donekle liberaliziraju, ustrojava se kakva-takva parlamentarna demokracija te započinje život višestranačkog političkog sustava. ${ }^{38}$ Uspostavom građanskog društva nastaju i društvene klase posve neuskladivih životnih navika, svakodnevica i svjetonazora, što dovodi do onih oblika neravnopravnosti i sukoba kojima u

${ }^{34}$ Foucault, Psychiatric Power, 110.

${ }^{35}$ Premda se o liječenju ludila u Hrvatskoj može govoriti i prije 19. stoljeća, psihijatrija se kao znanstvena disciplina i kod nas kao i u Europi ustrojava tek u 19. stoljeću. Usp. Lavoslav Glesinger, "Povijest psihijatrije u Hrvatskoj", u: Ludnica i lučbarnica, ur. Marko Pećina i Stella Fatović-Ferenčić (Zagreb: HAZU, 2012), 18-88.

${ }^{36}$ Naslov poglavlja je navod preuzet iz Matoševa eseja Kult energije.

${ }^{37}$ Eric Hobsbawm, Doba kapitala (Zagreb: Školska knjiga, 1989).

${ }^{38}$ Rečeni procesi ponajprije su plod razdoblja između 1873. i 1880., u kojem je banovao Ivan Mažuranić. Usp. Mirjana Gross i Agneza Szabo, Prema hrvatskome građanskom društvu. Društveni razvoj u civilnoj Hrvatskoj i Slavoniji šezdesetih i sedamdesetih godina 19. stoljeća (Zagreb: Globus, 1992). Posebno usp. 12. i 13. poglavlje. 
pozadini nije samo ekonomski antagonizam, nego složeni i do tada neviđeni postupci izvođenja i raspodjele moći. ${ }^{39}$

Riječ je o općem preustroju modela funkcioniranja društvenog života u kapitalističkim državama zapadne Europe koji se može pratiti od kraja 18. pa do početka 20. stoljeća. Tu je složenu socijalnu dinamiku Foucault objedinio pojmom biopolitike. ${ }^{40} \mathrm{U}$ najkraćim crtama, biopolitika je tehnologija političke moći nad životom cjelokupne populacije koja se najčešće izvodi strategijama normalizacije i discipliniranja ljudskog tijela. Budući da je baš ljudsko tijelo glavni resurs masovne kapitalističke proizvodnje, ono ubrzo postaje predmetom intenzivnog interesa $u$ različitim znanstvenim područjima, poljima i granama, poput medicine, etnologije, fizike, prava, pedagogije, kriminalistike, te također objektom sveobuhvatne kontrole koja se provodi u mnogobrojnim institucijama, od vojarni, tvornica i škola do zatvora, bolnica i ludnica. Moć biopolitike mogla je biti pokrenuta u društvima koja su za provođenje svojih ciljeva trebala ukupnu populaciju. Briga za njezino zdravlje, reprodukciju, dugovječnost, plodnost, stanovanje, prehranu, bila je od presudne važnosti. Zato se u 19. stoljeću, između ostalog, razvijaju demografija, eugenika, javno zdravlje, higijena, statistika, birokracija, standardizacija i regulacija spolnog

${ }^{39}$ Za uvid u opću povijest razvoja hrvatskog građanskog društva usp. Gross i Szabo, Prema hrvatskome građanskom društvu. Oblikovanje privredne elite u Zagrebu i njezinih životnih navika, običaja i svakodnevice analizira Iskra Iveljić, Očevi i sinovi. Privredna elita Zagreba u drugoj polovici 19. stoljeća (Zagreb: Leykam international, 2007). Životne navike, običaje i svakodnevicu devetnaestostoljetne studentske populacije Sveučilišta u Zagrebu istražuje Tihana Luetić, Studenti Sveučilišta u Zagrebu (1874-1914). Društveni život, svakodnevica, kultura, politika (Zagreb: Srednja Europa, 2012).

${ }^{40}$ Rođenje biopolitike naslov je seminara koji je Foucault držao akademske godine 1978/79. na Collège de France. Usp. Michel Foucault, Rođenje biopolitike (Zagreb: Sandorf - Mizantrop, 2016). Koncepte biopolitike, biomoći, guvernmentalnosti, discipline i normalizacije razvija i u drugim seminarima, knjigama i tekstovima kao što su Povijest seksualnosti, Nadzor i kazna, Psihijatrijska moć, Nenormalni, Znanje i moć, Sigurnost, teritorij, populacija. Usp. Foucault u popisu literature. Zbog prirode rada nije moguće osvijetliti tanane razlike i raznosmjerne veze između navedenih pojmova u Foucaultovu opusu. Posebno se to odnosi na međuovisnost moći i otpora, discipline i slobode te normalizacije i kažnjavanja. Treba dakle imati na umu da na primjer u Povijesti seksualnosti Foucault ističe međuovisnost moći i otpora; bez otpora odnosi moći ne mogu se uspostaviti, a otpor ih može promijeniti. Usp. Michel Foucault, Istorija seksualnosti. Volja za znanjem. (Beograd: Prosveta, 1982), 86. Na drugom mjestu tvrdi da "u odnosima moći nužno postoji mogućnost otpora, jer da nije postojala mogućnost otpora - nasilnog otpora, bijega, lukavstva, strategija koje preokreću situaciju - ne bi bilo odnosa moći". Prema tome "ne mogu postojati odnosi moći ako subjekti nisu slobodni (...); ako svim društvenim poljima protječu odnosi moći, to je zato što svugdje postoji sloboda". Michel Foucault, "The Ethics of Care for the Self as the Practice of Freedom", u: The Final Foucault, ur. J. W. Bernauer i D. Rasmussen, (Cambridge: MIT Press, 1994), 12. Za razumijevanje tih finih nijansi i njihovu podrobnu interpretaciju usp. izvrsnu studiju Krešimira Petkovića Istina kao kušnja (Zagreb: Plejada, 2018). 
ponašanja, nadgledanje rada, prakse testiranja i ispitivanja, kao snažni mehanizmi proizvodnje poslušnih, učinkovitih, discipliniranih i normiranih tijela.

Disciplinarno se društvo dakle uspostavlja radom institucija poput zatvora i diskursima kao što su kazneni zakon i pravo. U Nadzoru i kazni (Surveiller et punir: Naissance de la prison, $\left.{ }^{1} 1975\right)$ Foucault analizira kako sredinom 19. stoljeća dolazi do očite promjene u tehnologiji kažnjavanja i pristupanju zločinu. Ekstremno okrutno mučenje, doslovno trganje i komadanje tijela, koje se prije izvodilo u javnosti kao predstava da bi završilo bolnom smrću, zamjenjuje blaži oblik kažnjavanja. Zatvorenici se smještaju u novi tip kaznionica, u kojima njihovo ponašanje može biti stalno nadgledano i podvrgnuto pravilima. Riječ je tu o zaokretu u okviru kaznenog sustava, prema kojem se zločin više ne promatra kao čin usmjeren protiv vladara, nego protiv društva i cijele zajednice. Stoga Foucault tvrdi da je nadalje u fokusu pravne prakse socijalna rehabilitacija, a ne osveta svemoćnog cara. Čini se na prvi pogled da je prijelaz iz predmodernog okrutnog fizičkog kažnjavanja u novi kazneni sustav mnogo civiliziraniji i ljudskiji. Foucault međutim ima suprotan stav. Reforme dovode do organiziranog, sistematičnog kažnjavanja uz pomoć taktika stalnog nadgledanja tijela, regulacije njegova kretanja i tehnologizacije razmještanja. Dolazi do cjelovite kontrole, koja je u konačnici opresivnija od radikalne brutalnosti. Na taj se način u društveno tkivo ugrađuje moderni sustav discipline, koja se kapilarno širi u sva područja života zajednice, od edukacije i zdravstva do proizvodnje i tržišta. Radnici u tvornicama su poput zatvorenika u ćelijama; njihova tijela su imobilizirana i disciplinirana u sustavno oblikovanom i uređenom procesu raspoređivanja vremena i kretanja. Moderno društvo je zapravo u svojoj osnovi "zatvorski arhipelag". ${ }^{41}$ Konačni je cilj proizvodnja poslušnih i normalnih tijela, a to se čini uz pomoć suptilnih tehnika biopolitičkog mikromenadžmenta. Moglo bi se zaključiti da su, na primjer, razvoj školske i bolničke infrastrukture u 19. stoljeću, povećanje administracije i birokracije te težnja da se što veći broj pojava i osoba registrira i dokumentira naprosto rezultati modernizacije. No, Foucault prosuđuje da je to proizvod razvoja disciplinarnog društva, koje ima potrebu uspostaviti precizan i potpun sustav nadzora najvažnijeg resursa kapitalizma, tjelesne radne snage. Začuđujuće precizno viđenje tih promjena u nas je u ono vrijeme dao Matoš:

“Čovjek postade mašina, a mašina se pretvorila u nešto živo (...) tako se u društvenom životu čovjek automatisao, a automatski mehanizam njegovih izuma se humanizovao. Na velikim tvorničkim prostorima (...) pojedinac naprosto iščezava (...) pa (je) to iščezavanje pojedinačne volje i energije u kolosalnim organizacijama, karakteristično tek za noviju civilizaciju (...). Činjenica je da u golemim mehanizmima modernih organizacija pojedinačna volja iščezava sve više i više (...) a

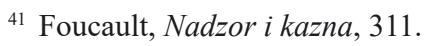


zamjenjuje je nešto kaotično, tamno i zagonetno što živi kao mašina u pokretu i što kao duša gomilâ guta sve individualno i pojedinačno. Pojedinac (...) se utopio u jedinstvu energije društvenog mehanizma, jer postoji tek kao dio sveopće volje, kao atom velikog mehanizma poput vijka ili točka u komplikovanom kolosalnom stroju. Život se pretvara u mehanizam kao i rad". ${ }^{2}$

Mehanicističke i termodinamičke metafore, tipične za tehnicistički jezik 19. stoljeća, Matošu su nedvojbeno poslužile da opiše način preobrazbe pojedinca u potpuno kontroliran organizam uronjen u proces cijeđenja što veće učinkovitosti. Riječ je o posve preciznoj manipulaciji tijelom "koje se može podčiniti, koje se može iskoristiti, preobraziti i usavršiti”. ${ }^{43}$ Takva moć koja život u cijelosti nastoji motriti, regulirati i iz njega izvući profit, prema Foucaultu, glavno je obilježje modernih kapitalističkih društava. Točnije, to je obilježje biopolitike kao novog vida političke i ekonomske racionalizacije "pitanja što su ih praksi upravljanja postavljali fenomeni svojstveni skupu živih bića konstituiranih u populaciju: zdravlje, higijena, natalitet, dugovječnost, rase". ${ }^{44}$ Taj novi oblik vladanja Foucault naziva guvernmentalnost (gouvernementalité). Guvernmentalnost je u načelu proces preobrazbe moći koji rezultira razvojem posebnih aparata vladanja (appareils) i serija znanja (savoirs). To je

“cjelina oblikovana institucijama, procedurama, analizama i refleksijama, kalkulacijama i taktikama koji omogućuju izvođenje ove vrlo posebne, čak vrlo složene moći koja za svoj cilj ima stanovništvo, političku ekonomiju kao prevladavajući oblik znanja i aparate sigurnosnih službi kao temeljni tehnički instrument". ${ }^{45}$

Pretpostavku da se hrvatsko buržoazijsko društvo u trećem desetljeću 19. stoljeća razvijalo, kako je Matoš naslućivao, kao guvernmentalističko druš-

${ }^{42}$ Antun Gustav Matoš, "Kult energije", u: Sabrana djela. Feljtoni, impresije, članci II, sv. XVI, ur. Vida Flaker (Zagreb: Mladost, 1973), 103-104.

${ }^{43}$ Foucault, Nadzor i kazna, 138.

${ }^{44}$ Foucault, Rođenje biopolitike, 320.

${ }^{45}$ Michel Foucault, Security, Territory, Population (New York: Palgrave Macmillian, 2009), 144. Petković napominje da Foucault guvernmentalnost shvaća kao "moći vođenja stada, omnes et singulatim, cijele populacije i svakog pojedinačno, kao moći vođenja duše, odnosno kao liberalna guvernmentalnost koja polazi od političke ekonomije i tržišta kao mehanizma istine”. Petković, Istina kao kušnja, 127. Iz različitih oblika distribucije moći u Foucaultovu radu Petković izvodi poticajnu tipologiju kažnjavanja prema kojoj guvernmentalnosti odgovara responsibilizacija. Riječ je o dresuri vladara "mrkve kojom [vladari, op. a.] čine samointeresne subjekte odgovornima". Pritom se javlja uskrata kao "sredstvo kontrole neželjenog ponašanja" (Isto, 132). Dakle, guvernmentalnost se nadalje shvaća kao "vođenje sebstva, ali na ukupnoj razini stanovništva, unutar šireg političkog okvira" (Isto, 97). 
tvo, potvrđuju radovi naših mlađih povjesničara. O odnosu prema tijelu u okviru onodobnog školskog sustava pisao je Dinko Župan. ${ }^{46}$ Vodeći se upravo Foucaultovim analizama, Župan tvrdi da je školski aparat služio u manjoj mjeri poučavanju, a u većoj discipliniranju tjelesnosti i reguliranju ponašanja učenika. Riječ je o tome da je modernizacija školstva, koja je uzela maha u vrijeme Mažuranićeva banovanja (1873-1880) i provodila se u skladu s prosvjetiteljskim i humanističkim idejama, bila također i "najbezbolniji način distribucije i reprodukcije poželjnih normi i vrijednosti disciplinsko-birokratskog društva. (...) Pedagoški diskursi 19. stoljeća, zajedno s tadašnjim medicinskim diskursima, imali su presudnu ulogu u formiranju odnosa školskih vlasti prema tjelesnosti učenika i učenica". ${ }^{47}$ Budući da je objekt biopolitike ljudsko tijelo, uređivanje odnosa prema spolnosti imalo je tada nezaobilaznu ulogu. Prema Foucaultu, buržoazijsko kapitalističko društvo 19. stoljeća spolnost doživljava dvostrano. S jedne strane produktivno, što se očituje brigom za fizičko zdravlje i uspješnu prokreaciju populacije. S druge pak strane restriktivno, zbog straha od degeneracije povezane sa spolnošću. Nelagoda se naime javlja uslijed mogućnosti da oslobađanje spolnosti i njezinih učestalih perverznih manifestacija dovede do smanjene učinkovitosti radno sposobnog stanovništva te do opće depopulacije. Ograničavanje spolnog života izvodi se patologizacijom dječje spolnosti i njezinim strogim nadgledanjem, medikalizacijom takozvane nenormalne spolnosti te zanemarivanjem, sputavanjem i ocrnjivanjem ženske spolnosti. Biopolitičko organiziranje i funkcionaliziranje učinkovitog stanovništva, sputavanjem i normiranjem tijela pojedinaca, koristi spolnost kao jedan od najpodesnijih resursa. Upravo se pomnom kontrolom spolnosti, reguliranjem spolnog ponašanja, upravljanjem spolnog razvoja, suzbijanjem spolnih bolesti, liječenjem nenormalne spolnosti, ekonomizacijom spolnih navika, pomnom distribucijom zabranjenih oblika spolnosti, djelotvorno upravlja životom populacije.

U Hrvatskoj druge polovice 19. stoljeća seksualnost je "postala problem koji su trebali riješiti pedagozi i liječnici". ${ }^{48}$ Župan analizira restriktivan odnos prema ženskoj spolnosti u kontekstu proizvođenja krotkih tijela spremnih za reprodukciju, a ne nadraženih tijela u potrazi za užitkom. Iz njegovih se primjera vrlo lijepo vidi kako je biopolitička regulacija spolnog života žena povezana s disciplinarnim mehanizmima zabrane i nadgledanja u okviru školskog sustava. Posebno je zanimljiv primjer javnih plesova, koji su funkcionirali, s jedne strane, kao mehanizam za pronalaženje partnera u okviru zadanih

\footnotetext{
${ }^{46}$ Dinko Župan, "Odnos prema tijelu unutar hrvatskog školskog sustava druge polovine 19 stoljeća", Radovi Zavoda za hrvatsku povijest 40 (2008): 189-209.

${ }^{47}$ Isto, 189-190. Prvi je dio navoda djelomično preinačen, op. a.

${ }^{48}$ Isto, 192.
} 
društvenih normi, "građansko tržište udaje" ${ }^{49}$ ali su s druge strane bili prijetnja razvijanju nepoćudne spolnosti koja bi štetila uspješnoj prokreacijskoj politici. Zbog toga su "pedagozi i učitelji savjetovali djevojke kako da izbjegnu pogubni utjecaj plesnih zabava", a najbolji je način bio bogobojazno samopropitivanje, ne bi li se opasne požude, koje su se javile tijekom ispraznog veselja, uspješno ugušile. ${ }^{50}$

Pedagogizaciju dječje spolnosti Župan pak pronalazi u onome što je Foucault nazivao "ratom protiv onanije" ${ }^{51}$ I u ono vrijeme u Hrvatskoj, kao i u drugim europskim zemljama, masturbacija se smatrala poremećajem koji može prouzrokovati čitav niz novih i još težih poremećaja i bolesti. Župan donosi brojne i vrlo sočne primjere iz tekstova pedagoga i liječnika u kojima se izriču nedvosmislena upozorenja o štetnosti samorune. Premda se to ne spominje, ta su mišljenja bila oblikovana na osnovi prvog europskog priručnika o masturbaciji, švicarskog liječnika Tissota, L'onanisme, ou dissertation physique sur les maladies, produites par la masturbation, objavljenoga 1760, a kod nas dostupnog već 1794 . na njemačkom jeziku. ${ }^{52}$ Župan naime ekstenzivno prenosi dio članka Nekoliko riečiji o samoruni, objavljenog 1872. u časopisu Napredak, broj 23, autora Velebićanina, dio koji je ustvari parafraza Tissotovih teza o onaniji kao smrtonosnoj aktivnosti. Da su ondašnji medicinski eksperti u Hrvatskoj bili upoznati s Tissotovom knjigom svjedoče i tekstovi iz Liečničkog viestnika o onaniji kao uzročniku težih i lakših mentalnih oboljenja. ${ }^{53}$

Očito je da je nadzor dječje spolnosti u okviru pedagoških institucija u Hrvatskoj druge polovice 19. stoljeća povezan s praksama normalizacije tijela i higijenizacije stanovništva. Također je očito da su te prakse neodvojive od onoga što je Foucault nazivao kompleksom nenormalnog koji se oblikuje u isto vrijeme kada se oblikuje kompleks dječje spolnosti te kada onanija "postaje pedagoški i medicinski problem koji spolnost uvodi u polje nenormalnosti““.54

${ }^{49}$ Isto, 193.

${ }^{50}$ Isto.

${ }^{51}$ Isto, 195. Također Foucault, Istorija seksualnosti, 93.

${ }^{52}$ Samuel Auguste Andre David Tissot, Von der Onanie oder Abhandlung über die Krankheiten die von der Selbstbesleckung herrühren (Zagreb: Joh. Thom. Edlen von Trattnern, 1794).

${ }^{53}$ Usp. "Liečničko izvješće kralj. zemalj. zavoda za umobolne u stenjevcu, za god. 1885. od Dra. Ivana Rohačeka, ravnatelja toga zavoda", Liečnički viestnik, 1886 (8), br. 11: 171-182; "Godišnje izvješće kr. zemalj. zavoda za umobolne u Stenjevcu za god. 1886. od Dra. Ivana Rohačeka, ravnatelja zem. zavoda za umobolne”, Liečnički viestnik, 1887 (9), br. 5: 6573; "Iz stranih listova: kratak prikaz članka: L. Haškovec, Ereuthophobya (Časopis českych lékařů, 1900. br. 33)", Liečnički viestnik, 1900 (22), br. 11: 398.

${ }^{54}$ Foucault, Les anormaux, 180. O problemu medikalizacije i patologizacije spolnosti i utjecaju tih pojava na razvoj psihijatrije kasnije će biti više riječi. 
U svakom slučaju, sputavanje tijela zbog prevencije užitka omogućuje ustrojavanje kontrole čak i ondje gdje službeni represivni mehanizmi ne mogu doprijeti, kao što su obiteljska intima ili sama savjest. Patologizaciju spolnosti i izum nenormalnog psihijatrija će iskoristiti kako bi konstituirala područje djelovanja i vlastito znanje kao važnu polugu disciplinarnog društva i biopolitike.

Da je guvernmentalistička preobrazba moći određujuća za hrvatsko društvo u drugoj polovici 19. stoljeća, potvrđuje i rad Luke Pejića "Kriminal i represivni sustav u Osijeku na prijelazu iz 19. u 20. stoljeće promatran kroz elemente biopolitike i socijalne povijesti". Ne bi li se u ozračju "industrijske racionalizacije društvenih procesa, širenja birokratskih trendova i biopolitičkog normativnog nadzora" 55 osigurala produktivnost radne snage, trebalo je isključiti nove oblike devijantnog ponašanja i ilegalnosti. Pejić govori o općem trendu zanimanja politike za tijelo u okviru zdravstvenih i pedagoških strategija, ali ga prvenstveno zanima discipliniranje tijela povezano s reformom kaznenog i zatvorskog sustava. Posebno je zanimljivo što je prijestupništvo tu dovedeno u vezu s nenormalnošću, premda taj suodnos nije preciznije analiziran. Pejić zaključuje da "stvaranjem veze između zločinačkog i patološkog ponašanja" 56 dolazi do proizvodnje takozvanog kriminalnog objekta koji se u novoj distribuciji moći ne lišava života ili isključuje iz optjecanja kapitala, nego se različitim tehnikama njegovo tijelo promatra, poboljšava, normalizira i, što je najvažnije, održava u sustavu kao mogući izvor produktivnosti.

Politika osnivanja bordela i poduzetništvo povezano s prostitucijom tome vjerno svjedoče. Pejić daje kratak pregled razvoja prostitucije u Habsburškom Carstvu i Austro-Ugarskoj Monarhiji, ukazujući na činjenicu da je kaznena zakonska regulativa samo jedan način postupanja s najstarijim zanatom. Prostitucija je u 19. stoljeću postala predmet javnoga zdravlja i birokracije; prostitutke su bile pomno evidentirane, uvedene u medicinske registre te su se prekršajno kažnjavale zbog neposluha. "U najkraćim crtama, obrisi društvenog odnosa prema prostituciji bili su otprilike ovakvi - djelatnost je bilo potrebno moralno osuditi (...) redarstveno i medicinski nadzirati, ali i porezno iskoristiti". ${ }^{57}$ Uzevši za primjer okolnosti u Osijeku fin de sièclea, Pejić je opisao hrvatski pandan onodobnog sustava prostitucije, za koji je Foucault tvrdio da obuhvaća složene odnose svodnika, prostitutki i policije. Cilj je takvoga sustava vratiti u kruženje kapitala profit koji može biti izlučen iz spolnog užitka. Pritom se javlja nekolicina proturječja: spolni je užitak marginaliziran ili moralno osuđen, ali se tolerira i svoju cijenu postiže upravo zbog zabrane; prostitucija se mora nadgledati, ali to čine i kriminalci i policija istodobno.

${ }^{55}$ Luka Pejić, "Kriminal i represivni sustav u Osijeku na prijelazu iz 19. u 20. stoljeće promatran kroz elemente biopolitike i socijalne povijesti”, Scrinia Slavonica 15 (2015), 134.

${ }^{56}$ Isto, 143.

${ }^{57}$ Isto, 154. 
"Vraćen na taj način u normalno optjecanje kapitalizma, profit iz spolnog užitka ostvarit će sekundarni učinak osnaživanja postupaka nadgledanja i posljedično uspostave onoga što bi se moglo nazvati podzemnom moći koja je naposljetku vraćena da bi utjecala na svakodnevno, individualno i tjelesno ponašanje ljudi: disciplinarni sustav prostitucije (...). Uz vojsku, školu i psihijatrijske bolnice, prostitucija, onako kako je bila organizirana u 19. stoljeću, ponavljam, sustav je discipline čiji se ekonomski i politički utjecaj može smjesta vidjeti." ${ }^{58}$

Pejić analizu završava razmatranjem discipliniranja otporaškog djelovanja socijalistički orijentiranog dijela radničkog pokreta, ali i same regulacije rada u tvornicama kao oblika standardizacije i optimalizacije tijela u proizvodnji. Ustrojavanje i jačanje radničkog pokreta u vrijeme industrijalizacije Osijeka u drugoj polovici 19. stoljeća prislilo je vlast da pokrene učinkovitu represiju protiv sve

"organiziranijih, uglavnom tvorničkih radnika, svjesnih svog društvenog položaja. (...) U namjeri formiranja nadzirane i produktivne radničke klase, političke su vlasti provodile čitav niz zakona koji pojedincu nisu ostavljali mnogo mogućnosti u izboru između industrijske eksploatacije i zatvora. Drugim riječima, svi prosjaci, beskućnici i štrajkaši bili su privođeni i kažnjavani, na ovaj ili onaj način.. ${ }^{59}$

U novoj ekonomiji mehanizama moći radnici, prosjaci, beskućnici, dakle svi oni koji odbacuju društveni ugovor "cirkuliraju društvenim tijelom, ali ih društveno tijelo ne prepoznaje kao svoj dio". ${ }^{60}$ Ta se velika drugost, kako je naziva Foucault, u 19. stoljeću više ne isključuje iz društva; pravno-političkim te pravno-medicinskim, točnije psihijatrijsko-forenzičkim diskursom društvo tu drugost definira oblikujući tako polje nenormalnosti presudno za pokretanje sofisticiranih normalizacijskih uređaja. Kraljevski zemaljski zavod za umobolne u Stenjevcu i hrvatska psihijatrija u to doba bili su jednim dijelom baš takav uređaj. U trenutku kada Krpanov anarhizam, socijalizam, revolt i neposluh sudska vlast nije željela ili nije mogla primjereno kazniti, u pomoć priskače psihijatrija. Psihijatrijsko znanje "omogućuje da se smjesta prepozna politički pokret koji se doista može odobriti i koji se mora obezvrijediti" ${ }^{61}$ To znanje svoju moć oblikuje povezujući se na vrlo složen i proturječan način s kriminalistikom, pravom i medicinom, što na koncu rezultira preuzimanjem uloge društvene brane pred nadiranjem različitih oblika patološkog, devijan-

\footnotetext{
${ }^{58}$ Foucault, Psychiatric Power, 111.

${ }^{59}$ Pejić, "Kriminal i represivni sustav", 160, 163.

${ }^{60}$ Foucault, Les anormaux, 89.

${ }^{61}$ Isto, 143.
} 
tnog, moralno neprihvatljivog ili politički opasnog ponašanja. Stenjevečki je Zavod počesto služio kao biopolitički aparat kojim se određeni oblik života, tek neznatno nekodiran i nenormiran, ali ne nužno i bolestan, disciplinarnim tehnikama nastojao privesti društvenim kodovima i normama. Psihijatrijsko je znanje uporno i dosljedno pothranjivalo moć toga aparata; ono je strateški korišteno u težnjama da se ukupno stanovništvo što učinkovitije organizira, nadgleda, razmjesti i iskoristi. Taj proces guvernmentalizacije populacije, nedvojbeno prisutan i u onodobnoj Hrvatskoj, neodvojiv je od onoga "što su tehnike segregacije značile za psihijatriju, tehnike discipline za kazneni sustav, a biopolitika za medicinske institucije". ${ }^{62}$

\section{Paranoia originaria kao paranoia socialis}

Na zalazu 19. stoljeća stenjevečki dosje socijalista i anarhista Miloša Krpana doslovno buja, povijest bolesti cvate zasađena u plodno tlo cijelog niza kulturnih, društvenih i pseudoznanstvenih teorija kojima odjekuje opći osjećaj povezan sa svjetonazorom fin de sièclea: onemoćalost, nazadnost, trulež, degeneracija, nenormalnost. Krpanov predmet, u kojemu se isprepleću različiti jezici, od medicine i prava do kriminalistike i ekonomije, te rad državnih uređaja poput zatvora, ludnice, škole i suda, mjesto je izravna susreta s uvidom u način uspostave psihijatrijskoga znanja kao društveno iskoristive normalizacijske moći. Može se stoga pretpostaviti da je Krpanu pripisana dijagnoza "paranoia originaria" zapravo psihijatrijsko pothranjivanje socijalne paranoje o najezdi degeneriranih i nenormalnih na slabašno tijelo hrvatske buržoazije u razvoju. Tu paranoidnu konstrukciju društvo izgrađuje i podupire različitim mehanizmima i taktikama, nastojeći očuvati privid vlastite stabilnosti te tako spriječiti provalu inherentnih proturječja i kriza u poprilično nerazvijen korpus tek zamišljene nacionalne zajednice. Na taj je način sudbina pobunjenog učitelja iz Dubovika pravi primjer ustroja psihijatrije kao guvernmentalističkog državnog uređaja i modela biopolitičkog upravljanja. Njegova transformacija iz anarhista u degenerika pruža uvid u modele funkcioniranja psihijatrijskog diskursa i institucije Zavoda u složenom procesu oblikovanja hrvatske građanske kulture kao zdrave etničke zajednice normalnih pojedinaca.

Godine 1897., kada je Krpan prvi put primljen u stenjevečki Zavod, hrvatski su liječnici i psihijatri putovali na XII. međunarodni medicinski kongres koji se održavao u Moskvi. U Liečničkom viestniku za mjesec kolovoz u rubrici Sitne viesti, osim popisa sudionika, izvora financiranja i za putovanje važnih naputaka, navodi se i to da su "u obćih skupštinah (...) na dnevnom redu (...) predavanja" između ostalih i "R. bar. Krafft-Ebing (Beč): Aetiologie der progresiven Paralyse" te "C. Lombroso (Turin): Les nouveaux horizons et

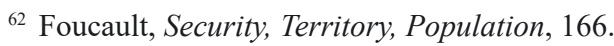


les nouvelles applications de la psychiatrie". ${ }^{63}$ Ova kratka informacija otisnuta na rubovima mjesečnika Sbora liečnika kraljevina Hrvatske i Slavonije tek je ilustracija utjecaja što su ga na onodobnu znanstvenu i stručnu zajednicu pa i na cjelokupnu hrvatsku javnost izvršili radovi autoriteta koji su oblikovali opće mnijenje i senzibilitet epohe. Pionirska djela u području spolne psihopatologije austrijskog psihijatra Richarda von Krafft-Ebinga i u području kriminalističke antropologije talijanskog liječnika i kriminologa Cesarea Lombrosa nisu bila samo dio svakodnevne lektire prvih hrvatskih psihijatara i sudskih vještaka. Njihove često kontroverzne, ali vrlo utjecajne ideje posredno su se, školskim, medicinskim i pravnim sustavom, širile onodobnim hrvatskim društvom pokrećući i podmazujući rad najvažnijih normativnih i disciplinarnih mehanizama, potičući istodobno osjećaj straha od izraženoga rasta degeneracije u novom naraštaju.

Utjecaj Krafft-Ebingova nauka na razvoj naše psihijatrije bio je, čini se, izravan i razmjerno snažan. Nakon što je 23. prosinca 1873. Hrvatski sabor dostavio vladi na proglašenje tekst

"Osnove zakona o ustrojenju javne ludnice za obseg kraljevine $\mathrm{Hr}$ vatske i Slavonije (...) posebna je komisija u sastavu (...) protomedik Dr. Šlosser, tajnik zdravstvenog odsjeka zemaljske vlade Dr. Antun Schwarz (...) i pukovnijski liječnik Dr. Stjepan Magjarević (...) otputovala u ljeti godine 1874. u Graz, da prouči uređaj tamošnjeg zavoda za umobolne i da stekne praktična iskustva u tom pogledu. Zajedno s gradačkim inženjerom Jakominijem sastavili su oni opširan elaborat, datiran u Grazu dne 25. VI. 1874., u kojemu iznose smjernice za gradnju zavoda." ${ }^{64}$

U to je vrijeme Krafft-Ebing preuzeo dužnost upravitelja tek ustrojenog zavoda za umobolne u Feldhofu kraj Graza te je na tom mjestu ostao do 1880. Istodobno je kao vanjski suradnik držao profesuru na gradačkom sveučilištu poučavajući u psihijatriji studente medicine. Njegova su istraživanja u akademskoj zajednici već tada stekla izniman ugled. Objavio je zapažene radove o opsesivno-kompulzivnim i trenutnim mentalnim poremećajima koji su u psihijatrijskim krugovima bili ocijenjeni kao inovativni. Također je "bio začetnik i vodeći stručnjak u polju forenzičke psihijatrije, a njegov Lehrbuch der gerichtlichen Psychopathologie (1875) prvi je udžbenik na njemačkom govornom području kojim se je, kada je o pravnim pitanjima riječ, zagovaralo

\footnotetext{
63 “Sitne viesti”, Liečnički viestnik, 1897 (19), br. 8: 288.

${ }^{64}$ Glesinger, "Povijest psihijatrije u Hrvatskoj”, 83. Tekst Osnove tiskan je pod naslovom Osnova za građenje ludnice u Zagrebu. Hrvatski državni arhiv, UOZV, 79/115/18/11958.
} 
odvajanje psihijatrije od ostatka medicine". ${ }^{65}$ Vrlo je izvjesno da su prilikom posjeta zavodu u Feldhofu 1874. hrvatski liječnici i psihijatri upoznali KrafftEbinga. Da su se njegove metode liječenja iz gradačkoga razdoblja primijenjivale u Hrvatskoj, potvrđuje "Liečničko izvješće kr. zem. zavoda za umobolne u Stenjevcu za godinu 1882.”. U njemu se navodi da se kalium bromatum "kod umobolestnikah od epilepsije bolujući (...) rabio (...) po uputi dobivenoj od Krafft-Ebinga u Gradcu". ${ }^{66}$ Nakon što je 1886. tiskano prvo izdanje kultne studije Psychopathia Sexualis ${ }^{67}$ o spolnim perverzijama poput fetišizma, egzibicionizma ili sodomije te spolnim inverzijama poput homoseksualnosti, popularnost Krafft-Ebingova rada u znanstvenoj zajednici i u široj kulturnoj javnosti rasla je iz godine u godinu. Njegova predavanja bila su iznimno posjećena i prema sudu njegovih suvremenika glamurozna i senzacionalna, te su, kao i njegova spektakularna javna pokazivanja hipnoze, često bila popraćena novinskim izvještajima. ${ }^{68} \mathrm{O}$ razmjerima Krafft-Ebingove popularnosti i utjecaja ideja koje je svojim znanstvenim radom i kulturnim djelovanjem širio zorno svjedoči tiskani oglas za Levico "naravnu željeznu vodu rudnicu u kojoj je arsena". Levico se preporučuje u slučaju "slabokrvnosti, bliedobolje, škrofuloze, neuralgije, hysterije, neuredne mjesečnice (...), bolesti živaca, kože", a u tekstu reklame se navodi da vodu, između ostalih, preporučuje profesor Krafft-Ebing. ${ }^{69}$ Stoga ne zapanjuje činjenica da su u radovima naših prvih psihijatara i forenzičkih eksperata Krafft-Ebingova istraživanja zauzimala važno mjesto. Može se pretpostaviti da su širenjem utjecaja psihijatrije u javnosti i njezine primjene $u$ školstvu i pravu ${ }^{70} \mathrm{Krafft-Ebingove} \mathrm{ideje} \mathrm{na} \mathrm{posredan} \mathrm{način}$ sudjelovale u oblikovanju svjetonazora hrvatskog buržoazijskog društva na prijelazu 19. i 20. stoljeća.

${ }^{65}$ Harry Oosterhuis, Stepchildren of nature. Krafft-Ebing, Psychiatry, and the Making of Sexual Identity (Chicago-London: The University of Chicago Press, 2000), 85.

66 "Liečničko izvješće", Liečnički viestnik, 1883 (6), br. 7: 101.

${ }^{67} \mathrm{Za}$ vrijeme autorova života knjiga je doživjela dvanaest izdanja. U kratko vrijeme prevedena je na engleski, talijanski, francuski, mađarski, ruski, švedski, nizozemski, španjolski i japanski jezik. Usp. Oosterhuis, Stepchildren of nature, 87, 97.

${ }^{68}$ Isto, 94-95.

69 “Levico", Liečnički viestnik, 1888 (10), br. 6: 95.

${ }^{70}$ To prelaženje psihijatrijske moći u druga društvena područja Foucault naziva njezinom psifunkcijom, čiji su najočitiji vidovi psihijatrija, psihopatologija, psihosociologija, psihopedagogija, psihokriminalistika i psihoanaliza. "Psi-funkcija je prekrila sve disciplinarne sustave: školu, vojsku, radionicu itd. Drugim riječima, psi-funkcija nameće disciplinu svima onima koji ne bi mogli biti disciplinirani. Kadgod neki pojedinac ne bi mogao slijediti školsku disciplinu, disciplinu radionice, vojske i, ako do toga dođe, zatvora, tada nastupa psi-funkcija. (...) Psi-funkcija je bila diskurs i establišment za sve modele individualizacije, normalizacije i subjektivacije pojedinaca u disciplinarnom sustavu." Usp. Foucault, Psychiatric Power, 85-86. 
Riječ je, između ostalog, o stanovitom preusmjeravanju zanimanja za spolnost. Tradicionalni pogled na etiku braka i prokreacije nije se doduše znatno promijenio, ali se promijenio način shvaćanja spolnih nastranosti. Umjesto kršćanske osude i nametanja osjećaja grijeha i krivnje, javlja se zabrinutost "za depopulaciju, slabljenje države i podrivanja javnog reda; nadasve spolne su se nastranosti počele shvaćati kao medicinski problem". ${ }^{71} \mathrm{U}$ tom se pogledu ne čini neobičnim već navedeni podatak da je prva studija koja je štetnost masturbacije izravno povezivala sa slabljenjem i oštećenjem nervnog sustava i mozga L'onanisme, ou dissertation physique sur les maladies, produites par la masturbation, švicarskog liječnika Tissota, tiskana na francuskom jeziku 1760., u Zagrebu bila dostupna već 1794. na njemačkom jeziku. ${ }^{72}$ Da su se Tissotove teze koristile kao postojana znanstvena istina potvrđuje primjerice "Godišnje izviešće kr. zemaljskog zavoda za umobolne u Stenjevcu za god. 1880.", u kojemu se navodi da je onanija uzrokovala duševnu bolest petorice muškaraca. ${ }^{73}$ "Ubrzo nakon objavljivanja Tissotove knjige u Francuskoj pokrenut je problem, diskurs, kolosalno brbljanje o masturbaciji koje se nije zaustavilo cijelo stoljeće". ${ }^{74} \mathrm{Ni} \mathrm{u} \mathrm{hrvatskoj} \mathrm{medicini} \mathrm{nije} \mathrm{naprosto} \mathrm{riječ} \mathrm{o} \mathrm{kon-}$ tinuitetu zastupanja konzervativnih ideja i religioznom moraliziranju, nego o "somatizaciji i patologizaciji masturbacije". Svrha toga procesa u najširem je smislu uspostava masturbacije kao "difuzne, opće i polimorfne etiologije koja omogućuje da se (...) određena zabrana spolnog ponašanja poveže $s$ cijelim patološkim poljem uključujući i smrt". Budući da "masturbacija postaje uzrok, univerzalna uzročnost svake bolesti", spolnost se odjednom premeće u medicinski instrument kojim se može "objasniti sve ono što je inače neobjašnjivo". ${ }^{75}$

Medikalizacija spolnosti u 19. stoljeću povezana je s nekolicinom međusobno isprepletenih procesa. Javlja se strah od prekobrojnosti stanovništva koja može dovesti do porasta bolesti i novih ratova. Posljedica je toga izum kontracepcije i razvoj politike kontroliranog rađanja u drugoj polovici 19. stoljeća. Uslijed potrebe da stekne ugled, uspostavljajući nedvosmislenu razliku spram navodne aristokratske lakoumnosti te raskalašenosti radništva i seljaštva, građanska klasa spolnost povezuje s ulogom obitelji, javnim moralom, društvenim reformama te s konceptima iskoristivosti, samodiscipline i

\footnotetext{
${ }^{71}$ Oosterhuis, Stepchildren of nature, 23.

${ }^{72}$ Usp. ovdje poglavlje Mi smo napredak platili grdobom, posebno dio o pedagogizaciji dječje spolnosti te bilješku 46.

73 "Godišnje izviešće kr. zemaljskog zavoda za umobolne u Stenjevcu za god. 1880", Liečnički viestnik 5 (1881), br. 3: 43. U liječničkim izvješćima kasnijih godina onanija se još češće navodi kao jedan od uzroka ludila muškaraca. Usp. bilješku 47.

${ }^{74}$ Foucault, Les anormaux, 219.

${ }^{75}$ Isto, 223, 226, 227.
} 
odgovornog ponašanja. "Smatralo se da su medicina, obrazovanje i socijalna higijena, prije negoli kazneni zakon, tehnike sprečavanja razvrata i oblikovanja društveno prihvatljivog standarda spolnosti" ${ }^{76} \mathrm{Na}$ taj način organizirana i nadzirana, spolnost buržoazijske klase bila je snažan normalizacijski mehanizam, u osnovi pokrenut proturječnom idejom očuvanja vitalnosti i snage novonastale nacionalne zajednice. Proturječnom utoliko što se takozvana depopulacijska histerija u modernim buržoazijskim društvima s kraja 19. stoljeća javlja upravo zbog očitih posljedica modernizacije i liberalizacije kao što su porast spolno prenosivih bolesti, učestalo javno očitovanje spolnih izopačenosti i legalizacija prostitucije. Navodno slabljenje biološke supstancije nacije zapravo je izraz rastuće potrebe kapitalističke ekonomije za zdravim, snažnim $\mathrm{i}$ ispravno upravljanim tijelom pojedinca. Smisao postojanja mehanizma spolnosti, upozorava Foucault, nije naprosto reprodukcija, nego umnožavanje, novačenje, objedinjavanje i podrobno pronicanje u tijela te sveobuhvatna kontrola stanovništva. ${ }^{77}$ Stoga se javljanje spolnosti u polju medicine "ne može razumjeti u okviru znanosti ili ideologije, ili u okviru povijesti mentaliteta, ili u okviru društvene povijesti bolesti, već naprosto povijesnim proučavanjem tehnologija moći". ${ }^{78}$

Medikalizacija i psihologizacija spolnosti, i uopće izmišljanje i upotreba znanja o spolnosti u svrhu društveno-političke kontrole pojedinaca i čitave zajednice, nisu zaobišli ni hrvatske zemlje u drugoj polovici 19. i početkom 20. stoljeća. Spolnost je imala središnje mjesto uglavnom u nacionalističkim diskursima kojima je u očištu bilo provođenje uspješne zdravstvene politike. Pišući o spolnim politikama obrazovanja žena u Banskoj Hrvatskoj, Župan ističe kako je "o reproduktivnom zdravlju žena ovisio (...) opstanak i 'zdravlje' nacije. Zato je kroz nacionalnu zdravstvenu politiku trebalo kontrolirati reproduktivne sposobnosti ženskog tijela".${ }^{79} \mathrm{U}$ pozadini tih diskursa odjekivala je opsesija degeneracijom u novom naraštaju, koja se počesto dovodila u vezu s nereguliranim vidovima spolnog života. Kada je na prijelazu stoljeća uslijed legalizacije prostitucije ${ }^{80}$ došlo do širenja veneričnih bolesti i među populacijom zagrebačkih studenata, ondašnja su studentska glasila počela ši-

${ }^{76}$ Oosterhuis, Stepchildren of nature, 28.

${ }^{77}$ Michel Foucault, Istorija seksualnosti. Volja za znanjem (Beograd: Prosveta, 1982), 95.

${ }^{78}$ Foucault, Les anormaux, 210.

${ }^{79}$ Dinko Župan, Mentalni korzet. Spolna politika obrazovanja žena u Banskoj Hrvatskoj (18681918) (Osijek-Slavonski Brod: Učiteljski fakultet u Osijeku / Hrvatski institut za povijest, 2013), 136.

${ }^{80}$ Zbog složenosti i brojnih društvenih posljedica, osim kaznenopravnim normama, prostituciju se nastojalo regulirati redarstvenim i zdravstvenim propisima. "Bludni obrt" držao se pod nadzorom izdavanjem posebnih propisa za prostitutke, njihovom evidencijom i redovitim liječničkim pregledima. Usp. Dunja Pastović i Darija Željko, "Zakonodavni okvir uređenja prostitucije na hrvatsko-slavonskom području 1852. - 1929.”, Pravni vjesnik: časopis 
riti sanitarnu paniku. Bio je to zapravo odjek rastuće nelagode u buržoaskoj kulturi, izraz tjeskobe zbog moguće depopulacije nacije i straha od navodno umnoženih tjelesnih, psihičkih i moralnih nenormalnosti. Ti su kolektivni osjećaji najsnažnije pothranjivani sociobiološkim disciplinama poput darvinizma, degenerativne teorije i eugenike. Tako se 1898. u Novom dobu, listu praških studenata, nečistoća proglašava nakazom hrvatskog društva. "Razočaranost, razrovanost, nespokojenost, nemir velikog dijela mladeži posljedak je nečistog života (sa ženom ili bez žene), spolne pokvarenosti". ${ }^{81} \mathrm{Da}$ je to bio opći socijalni trend, potvrđuje i niz članaka Julija Gorjanića koje je dvanaest godina kasnije pod naslovom „Osvrt na seksualno pitanje“ objavljivao časopis Mlada Hrvatska. U njima se prostitucija kao izvorište spolnih bolesti i moralne dekadencije proglašava izravnom prijetnjom zdravlju naroda. Budući da "narod treba zdrave ljude", Gorjanić predlaže niz higijenskih mjera koje uključuju nadgledanje, pregledavanje, ispitivanje i spolno obrazovanje studenata. ${ }^{82}$

U drugoj polovici 19. stoljeća psihijatrija je na području hrvatskih zemalja institucionalizirana u dodiru s medicinom, pravom i forenzičkom znanošću "kao socijalna pomoć, kao higijena društvenog tijela u cjelini".

"Općenito uzevši, psihijatrija je s jedne strane pokrenula funkcioniranje sveukupne javne higijene kao medicine, a s druge strane ona je pokrenula funkcioniranje znanja, prevencije i mogućeg liječenja mentalnih bolesti kao apsolutno nužnog oblika društvene budnosti želi li se izbjeći određeni broj temeljnih opasnosti povezanih sa samim postojanjem ludila (...) Eugenika i psihoanaliza dvije su velike tehnologije koje nastaju na kraju XIX. stoljeća kako bi psihijatriji priskrbile pristup svijetu nagona." ${ }^{\text {83 }}$

Nije stoga nimalo neobično da su upravo hrvatski liječnici, pravnici, psihijatri i sudski vještaci bili u nas začetnici širenja eugeničkih ideja. "Znanost o popravljanju rase" ${ }^{" 84}$ zasnivala se na ideji da su "mentalne, moralne osobine

za pravne i društvene znanosti Pravnog fakulteta Sveučilišta J. J. Strossmayera u Osijeku 1 (2016), 29-53.

${ }^{81}$ Navod prema Luetić, Studenti Sveučilišta u Zagrebu, 290.

${ }^{82}$ Navodi i svi izvori prema Luetić, Studenti Sveučilišta u Zagrebu, 290-291.

${ }^{83}$ Foucault, Les anormaux, 109, 110, 124.

${ }^{84}$ Francis Galton, Inquiries into Human Faculty and its Development (London-New York: Dent and Dutton, 1907), 10. Prvo izdanje studije Inquiries into Human Faculty and its Development engleskog svestranog znanstvenika Francisa Galtona, koji je između ostaloga bio geograf, meteorolog, utemeljitelj diferencijalne psihologije, izumitelj identifikacije otiskom prsta, eugeničar, protogenetičar te rođak Charlesa Darwina, objavljeno je 1883. 
te narav ljudskih bića u cijelosti određene hereditarnošću". ${ }^{85}$ Temeljeći svoja shvaćanja na socijalnom darvinizmu, vjerujući da je biologija sudbina te da se pogubne društvene i psihičke osobine ljudi prenose s koljena na koljeno, Galton je eugeničko polje definirao kao "proučavanje društveno kontroliranoga djelovanja koje može poboljšati ili pogoršati rasne kvalitete budućih generacija" ${ }^{86}$ Eugeničke ideje neodvojive su od brojnih devetnaestostoljetnih znanstvenih i pseudoznanstvenih disciplina koje su se temeljile na shvaćanju da postoje biološki manje vrijedni pojedinci. Tako su i u hrvatskoj kulturi na prijelazu iz 19. u 20. stoljeće eugenička rješenja za navodno izvjesnu biološku propast nadolazećih pokoljenja oblikovana u dosluhu s kriminalističkom antropologijom, degeneracijskom teorijom, inačicama darvinizma i psihijatrijom.

Jedan od naših prvih eugeničara bio je Josip Šilović, pravnik, redoviti profesor kaznenog prava i filozofije prava te rektor Sveučilišta u Zagrebu. ${ }^{87}$ Pod utjecajem Lombrosove teorije rođenog zločinca, pokušavajući proniknuti u uzroke kriminalnih djela, Šilović je razvio zanimanje za biologiju zločina. Godine 1911. kao hrvatski izaslanik na 11. kongresu Međunarodne kriminalističke udruge Šilović je izložio rad pod naslovom „Pogibeljni zločinac“. U izlaganju se zalagao za nadziranje i preventivno društveno isključivanje bolesnih, umobolnih, degeneriranih, prosjaka, skitnica i alkoholičara, budući da se stupanj njihove pogibeljnosti po zajednicu, prema njegovu mišljenju, mogao znanstvenim uvidima objektivno odrediti. Kriminalistička antropologija i degeneracijska teorija, tvrdio je Šilović, pružale su svrhovit i dostatan metodološki aparat za sprječavanje i ovladavanje socijalnim anomalijama. Poput naših drugih društvenih higijeničara, svoje je stavove potkrepljivao različitim devetnaestostoljetnim pseudoznanstvenim hipotezama, poput one o "blastof-

${ }^{85}$ David Bradshow, "Eugenics: They should certainly be killed", u: A Concise Companion to Modernism, ur. David Bradshow (Malden: Bleckwell, 2005), 36.

${ }^{86}$ Isto, 36-37. Navod prema Diane Paul, Controlling Human Heredity 1856 to Present. Atlantic Highlands, NJ: Humanities Press. Usp. i ovo: "Eugeniku je još 1883. godine definirao britanski psiholog, antropolog i statističar Francis Galton kao 'znanost o popravljanju rase', koja uzima u obzir sve one faktore koji pojedincima s boljim osobinama daju veće šanse da prevladaju nad onima s manje prikladnim osobinama. Galton je u svojim statističkim istraživanjima na antropometrijskim podacima poput visine uočio pojavu tzv. reverzije prema mediokritetstvu, koja je kasnije u statističkoj terminologiji postala poznata kao linearna regresija. Iz ovoga populacijskog zakona Galton je derivirao želju za diferencijalnom reprodukcijom sposobnijih, i dio svoga rada posvetio je upravo istraživanju konstitucije genija. Paralelni razvoj statistike i metoda kvantifikacije te eugenike omogućio je u dvadesetom stoljeću sve veći utjecaj znanosti u određivanju državne populacijske politike”. Martin Kuhar, Eugenika u hrvatskoj medicini i njezin utjecaj na javnost u razdoblju od 1859. do 1945. (Središnja medicinska knjižnica, 2015), http://medlib.mef.hr/2226/1/Kuhar_M_disertacija_rep_2226. pdf (pristup ostvaren 10. I. 2020).

${ }^{87}$ Svi navodi Šilovićevih radova prema Kuhar, Eugenika u hrvatskoj medicini. Njihova interpretacija ponekad odstupa od Kuharevih zaključaka. 
toričnoj degeneraciji potomstva", kako bi pokazao da trovanje organizma alkoholom "prilikom začeća može dovesti do ozbiljnog oštećenja zametka koje rezultira tjelesnim i duševnim malformacijama te potencijalnom predispozicijom za društveno štetno ponašanje". ${ }^{88}$ Šilovićev je rad svojevrsna ilustracija djelovanja biomoći (Foucault): poluga znanstvenog znanja i rada institucija regulira, proračunava i razvrstava ljudska tijela u svrhu oblikovanja učinkovite populacijske politike. Zanimljivo je napomenuti da je Šilović smatrao kako je zločin "bio značajno povezan s duševnom bolešću, odnosno one su prema njemu imale zajednički izvor u tjelesnoj i duševnoj degeneraciji". ${ }^{89} \mathrm{Na}$ taj je način posredno ukazao na barem dva procesa kojima je ustrojena psihijatrija, dakako i hrvatska psihijatrija. U drugoj polovici 19. stoljeća znanost o ludilu odjednom pokazuje interes za zločin i povezuje se s jedne strane s pravom, a s druge strane proizvodi koncept nenormalnosti ne bi li društvo obranila od te potmule, neizravne prijetnje. Foucault je to ovako sažeo: "Kada zločin iznenada provali (...) bez motiva i bez razloga, tada istupa psihijatrija i govori: premda nitko drugi ne može unaprijed otkriti taj zločin što provaljuje, ja kao znanje, kao znanost o umnoj bolesti (...) moći ću precizno otkriti tu opasnost koja je svima drugima nepronična i neprimjetna". ${ }^{90} \mathrm{U}$ sprezi s pravom i kriminalistikom, povezujući iznenada ludilo s izbijanjem nagona, a izbijanje nagona s nenormalnošću, psihijatrija pronalazi put prema jednoj općoj ulozi "društvene moći". ${ }^{91}$

Potreba društva za medicinsko-pravnim autoritetom psihijatara javlja se dakle i u Banskoj Hrvatskoj u drugoj polovini 19. stoljeća. Psihijatri su postali kriminalistički stručnjaci, jedini koji mogu "razlučiti razliku između zločina i ludila i dati procjenu o onome što je opasno u svakom ludilu". ${ }^{92}$ Pokrenuto je društveno optjecanje takozvane psi-funkcije: utemeljena radom međusobnog cijepljenja medicine i prava, psihijatrijska moć vrlo brzo prelazi i u druge

${ }_{88}^{88}$ Tezu je postavio "švicarski psihijatar, entomolog i jedan od utemeljitelja istraživanja o posljedicama alkoholizma August Forel (1848-1931), kako bi pokazao da otrovanje organizma prilikom začeća može dovesti do ozbiljnog oštećenja zametka koje rezultira tjelesnim i duševnim malformacijama te potencijalnom predispozicijom za društveno štetno ponašanje. Forelovu su teoriju praktički bez propitivanja u 1910-im godinama preuzimali gotovo svi hrvatski autori koji su se na bilo koji način bavili problemima degeneracije i utjecaja alkoholizma i spolnih bolesti na potomstvo. Ona je omogućavala da se istovremeno sudjeluje u raspravama o tada popularnim teorijama degeneracije bez da se kompromitira - za hrvatski kontekst - vrlo važna tradicija zdravstvenog prosvjećivanja". Kuhar, Eugenika u hrvatskoj medicini, 14.

${ }^{89}$ Isto, 13-14.

${ }^{90}$ Foucault, Les anormaux, 112.

${ }^{91}$ Isto, 124.

${ }_{92}$ Isto, 259. 
znanstvene discipline. ${ }^{93}$ Djelovanje Frana Gundruma, prvog važnijeg eugeničara u Hrvatskoj, proizlazi upravo iz aktiviranja te medicinsko-pravne spone. Njegove rasprave o biologiji zločina, koje su se nadovezivale na teoriju evolucije, neolamarkizam i kriminalističku antropologiju, bile su pokušaj "rješavanja nekih od najvažnijih medicinsko-pravnih problema" s kraja 19. stoljeća. ${ }^{94}$ Budući da Gundrumov eugenički rad proizlazi iz njegova zanimanja za spolnost, prostituciju, nasljednu patologiju, zločin te degeneraciju uzrokovanu alkoholizmom, ${ }^{95}$ očito je da je u korijenu tih problema koncept nenormalnosti. Nenormalna osoba "predstavlja zgušnjavanje zabrinutosti nastalih oko fizičkog tijela, kriminala i spolnog nonkonformizma". ${ }^{96}$ Upravo su to bile i Gundrumove brige: zalagao se za obranu društva od zločinaca i degenerika, za zabranu sklapanja braka "za umobolne, idijote i padavičare" te za "sterilizaciju nepopravljivih zločinaca, tupoglavih, slaboumnih i silovatelja". ${ }^{97}$ Gundrum je "stvorio vezu između nekontrolirane i neregulirane spolnosti s jedne strane, i zločinačke etiologije s druge". ${ }^{98}$ Njegov se eugenički rad, drugim riječima, nedvojbeno kretao netom otvorenim poljem nenormalnosti, "velikim područjem djelovanja" 99 medicine i prava. "Taj kontinuum, čiji je jedan pol terapeutski, a drugi juridički, ta institucionalna mješavina, zapravo je odgovor na (...) socijalnu (...) opasnost". ${ }^{100}$ Tako je i Gundrumova eugenika prvenstveno bila metoda "povećanja društvene sigurnosti smanjenjem budućeg broja zločinaca". ${ }^{101}$ U knjizi Zdravstvo spolnog života nenormalnosti bolesnoga tijela suprotstavljena je spolnost kao mehanizam njegove regulacije.

"Jer može li biti veće grjehote nego li, da se ženi koji muškarac, ako boluje od kakve bolesti, za koju možda i znade, da je potomstvo njegovo može naslijediti? Nije li takav čovjek gotovo opasan čovječanstvu, što sije svoje sjeme, iz koga ne može da se rađa drugi nego bolesni, kržljavi pomladak; pomladak slab i tjelesno i duševno, koji će se lako razboljeti, dugo bolovati, koji ni u kom pogledu ne će ispuniti ono mjesto

\footnotetext{
${ }^{93}$ Usp. ovdje bilješku 64.

${ }^{94}$ Kuhar, Eugenika u hrvatskoj medicini, 18. Svi navodi Gundrumovih radova preneseni su iz Kuhareva teksta, a njihova interpretacija ponekad odstupa od autorovih zaključaka.

95 Isto, 18-19.

${ }^{96}$ Andrew N. Sharpe, Foucault's Monsters and the Challenge of Law (London-New York: Routledge, 2011), 47.

${ }^{97}$ Kuhar, Eugenika u hrvatskoj medicini, 21. Navod je iz teksta $O$ izlučenju zločinaca, objavljenog 1908. u 34. broju Mjesečnika Pravničkoga društva u Zagrebu.

${ }^{98}$ Isto, 23.

${ }^{99}$ Foucault, Les anormaux, 127.

${ }^{100}$ Isto, 34.

${ }^{101}$ Kuhar, Eugenika u hrvatskoj medicini, 25.
} 
u društvu čovječanskomu, koje bi morao; pomladak velim, koji bi sam jasno i glasno izjavljivao, da bi bolje bilo, da se uopće nije ni rodio!" 102

U Gundrumovoj je eugenici "tehnologija nenormalnog susrela jedan posve drugi proces normalizacije (...): svakodnevnu seksualnost". ${ }^{103}$ Očito je da se i u Hrvatskoj u zadnjoj četvrtini 19. stoljeća istodobno otvara polje nenormalnosti te ga se presijeca i premrežava problemom spolnosti. Kako je proces normalizacije spolnosti proistekao, između ostaloga, iz združivanja ideje hereditarnosti i teorije degeneracije, od njega je neodvojivo buđenje društvene potrebe za kontrolom reprodukcije. Foucault tvrdi da je prepoznavanje problema "hereditarnosti i degeneracije odmah primijenjeno na opće polje nenormalnosti kao analitička mreža koja ga kodira i dijeli" te stoga "medicinske i psihijatrijske analize funkcija reprodukcije postaju uključene u metode analiziranja nenormalnog". ${ }^{104}$

Radovi Bogomila Kohouta, općinskog liječnika u Kloštru Ivaniću, a kasnije i gradskog kotarskog liječnika u Ivanić-Gradu, potvrđuju činjenicu da je "umnožanje manje vrijednih degeneriranih pojedinaca"105 stanovita preokupacija jednog dijela onodobne hrvatske medicine. Riječ je o preventivnoj i socijalnoj medicini koja oslanjanjem na cijeli niz devetnaestostoljetnih pseudoznanstvenih disciplina živo sudjeluje u održavanju polja nenormalnosti. Uzimajući hereditarnu degeneraciju kao svoje metodološko polazište, Kohout je doduše nastojao umanjiti očito duboko ukorijenjen strah od različitih oblika društvene patologije. No, zato nije propustio svoj tip argumentacije osnažiti onim teorijskim tezama koje su upravo ustrajavale na "prvenstvu tijela kao određujućeg čimbenika ponašanja i mentalnih sposobnosti pružajući sveobuhvatno biološko objašnjenje za patološko stanje širokog spektra socijalnih problema". ${ }^{106}$ Premda je smatrao da je stupanj kulturne nelagode zbog rastućeg trenda degeneriranih pojava pretjeran, Kohout je u članku Degeneracija čovječjeg pokoljenja pokazao baš kako je "krajnja posljedica poruke degenerativističke teorije naturalizacija socijalnih i političkih prijepora". ${ }^{107}$

"Događaji koji su se počeli u novije doba u većoj mjeri očitovati, kao što su samoubojstvo, ludilo, zločin, syphilis, prostitucija, manje vjenčanja i djece, svratili su pažnju pojedinih sociologa i drugih

\footnotetext{
${ }^{102}$ Isto, 23. Navod je iz knjige Zdravstvo spolnoga života, izdane u Zagrebu 1914.

${ }^{103}$ Foucault, Les anormaux, 151.

104 Isto, 155.

${ }^{105}$ Bogomil Kohout, "Degeneracija čovječeg pokoljenja”, Liečnički viestnik, 1907 (29), br. 4: 103.

${ }^{106}$ Oosterhuis, Stepchildren of nature, 112.

107 Isto.
} 
strukovnjaka. Ti su počeli te pojave intensivnije proučavati i tako je nikla teorija o degeneraciji ljudstva. Ta je teorija imala znatan upliv i na neke druge discipline, na pr. na psychiatriju. Počela su se naime mnoga psyhiatrička pitanja intensivnije proučavati i mnogo, što je prije bilo tamno, sada je razjašnjeno. Upravo uplivom te teorije nikla je škola kriminalnih antropologa, te se po njihovom radu predavaju mnoga nesretna ljudska bića, koja bi bila za grijehe, ne svoje, nego svojih roditelja, kažnjena tamnicom, tamo, kamo spadaju - u ludnicu". ${ }^{108}$

"Umnožanje manje vrijednih degeneriranih pojedinaca" događa se uslijed napretka "u liječničtvu i higieni". ${ }^{109}$ Budući da je smrt kao posljedica epidemija teško izlječivih zaraznih bolesti u većoj mjeri pogađala slabije pojedince, razvoj medicine doveo je do njihova preživljavanja. To izravno nanosi štetu razvitku budućih naraštaja jer loš genetski materijal, umjesto da nestane, preživljava, reproducira se i tako oslabljuje zdravi dio populacije.

"Dobro su svakomu poznati ljudi s visokim ramenima, uzkim upalim grudnikom, koji se bore neprestano s "prehladom", a zanimivi su svojom pojavom radi bogate kose, nježne puti, čile, mladenačke živahnosti, duševne uzbudjenosti, a u svemu očite nježnosti, koja budi saučešće. Tuj se ogleda buduća degeneracija čovječanstva. Takovi individui po braku dolaze u sad zdrave porodice, pak snizuju vrijednost budućeg naraštaja. Tako će i dalje bivati, ako se ne nađu drugi uplivi, koji će priječiti, da se bolesti ne prenose na potomstvo. Haykraft tvrdi, da spriječavanje zaraznih bolesti oslabljuje čovječanstvo. Slabi su pogibali, a preostali stekli su [i]munost. Uvijek su preostajali samo najjači individui." $" 110$

Potpunim iskorjenjivanjem uzročnika zaraznih bolesti ljudski bi rod, prema Kohoutu, znatno oslabio. Budući da nije uputno spriječiti razvoj medicine, on smatra da "treba zakonom zabraniti ljudima, na kojima se iztiču pojave koje nasljedne bolesti, ženitbu i konkubinat, jer je to grijeh i proti vlastitoj djeci i proti ljudskom družtvu". ${ }^{111}$

U članku Higijena društva (Eugenia) napisanom nekoliko godina kasnije Kohout mnogo odlučnije zastupa tezu da od patološkog herediteta "prijeti pogibelj pogoršanja (degeneracije) ljudskog društva". ${ }^{112}$ Ne odbacujući lamar-

\footnotetext{
${ }^{108}$ Kohout, "Degeneracija čovječeg pokoljenja, 98.

109 Isto, 103.

${ }^{110}$ Isto, 104.

${ }^{111}$ Bogomil Kohout, "Degeneracija čovječeg pokoljenja”, Liečnički viestnik, 1907 (29), br. 5: 133.

112 Bogomil Kohout, "Higijena društva (Eugenia)”, Liečnički viestnik, 1913 (35), br 11: 548.
} 
kizam kao u prethodnome članku, u ovome promiče stav da pojedince, pa čak i cijele naraštaje, mogu degenerirati pauperizam, nepovoljni životni uvjeti ili pak alkoholizam. Drugim riječima, teške socijalne i ekonomske prilike dovode do toga da "kad djeca baštine tjelesna i duševna svojstva roditelja, baštine i većim dijelom i njihove mane, ili dispoziciju za njih". ${ }^{113} \mathrm{U}$ pravilu "pojavi degeneracije posljedica su ne samo nasljedstva, nego i socijalnih odnošaja". ${ }^{114}$ Primjerice

“dugotrajan naporan rad, koji počima već od rane mladosti, nedovoljna hrana, nezdravi stanovi, trajno duševno nezadovoljstvo, doveli su do oslabljenja individua. Da potomci takvih iscrpljenih obitelji budu manje vrijedni, poznato je sveopće". ${ }^{115}$

Kohoutova je eugenika tehnologija baratanja nenormalnim. Najuže povezana s "problemom hereditarnosti", očito je bila zamišljena kao "korekcija ljudskog nagonskog sustava" ${ }^{116} \mathrm{u}$ onom smislu u kojem je taj nagonski sustav patologiziran i zapravo neodvojiv od "organizacije ideje degeneracije". ${ }^{117}$ Unatoč stanovitim pokušajima ublažavanja osjećaja kulturne tjeskobe koja se javlja uslijed prijetnje od deformacije i propasti budućih naraštaja, Kohoutovo shvaćanje degeneracije svjedoči o nekoliko desetljeća ranije započetim procesima društvene normalizacije na području hrvatskih zemalja. Njegovi radovi potvrđuju da je i u nas potkraj 19. i na početku 20. stoljeća "nosografija abnormalnih stanja - raspoređena po razvedenom i istodobno policefaličnom, nestabilnom, plutajućem, klizavom tijelu hereditarnosti - formulirana u okviru utjecajne teorije degeneracije". ${ }^{118}$ Poput psihijatrijske moći, kojoj je ideja degeneracije "pružila ogroman poticaj", Kohoutova eugenika "funkcionira naprosto kao zaštita od nepopravljivo opasnih, ljudi nenormalnog stanja, čijom žrtvom društvo može postati". ${ }^{119}$ Uz pomoć metodologije patološkog herediteta ona je "postala disciplina znanstvene zaštite društva, postala je znanost biološke zaštite vrste". ${ }^{120}$

\footnotetext{
${ }^{113}$ Bogomil Kohout, "Higijena društva (Eugenia)”, Liečnički viestnik, 1913 (35), br 12: 607.

${ }^{114}$ Isto, 604.

${ }^{115}$ Isto, 548.

${ }^{116}$ Foucault, Les anormaux, 124.

117 Isto, 123, 125. U članku "Degeneracija čovječjeg pokoljenja” Kohout jasno ističe pogibeljnost patološke usmjerenosti ljudskog roda na nagon. Borbu protiv "raznježenja" treba voditi "samostegom" jer ona je "najuspješnija obrana od strasti“. Kohout, "Degeneracija čovječjeg pokoljenja", 133.

${ }^{118}$ Foucault, Les anormaux, 297.

119 Isto, 298.

${ }^{120}$ Isto, 298-299.
} 
"Kako brakovi duševno bolesnih dovode do teške degeneracije i do izumiranja cijelih porodica, dovoljno je poznato iz historije. Ovo hereditarno opterećenje pojavlja se kao apsolutna nesposobnost fizička i duševna za borbu za opstanak. (...) Poznat je taj nepregledni niz čudakovića svake vrsti, ekscentričnih, lijenčina, lakoumnika, proteplica. U takvim individuima klije zametak zločina i niče zločin sam. Vidimo da se žene bez zapreke tuberkulozni, leutičari, duševno defektni. Tu bi trebalo zakona, koji bi ograničio slobodu braka i zabranio ženitbu pijanicama, notoričkim zločincima, sifilitičarima, duševno bolesnima. (...) Troši se uopće radi neumjesne sentimentalnosti na potpuno beznadnu dobrotvornost, koja besmislenim čuvanjem slabih vodi direktno do štete zdravih, jakih, inteligentnih, do degeneracije". ${ }^{21}$

Kohout je ovdje, između ostaloga, neizravno ukazao na ulogu koju je teorija degeneracije izvršila na oblikovanje hrvatske psihijatrije kao aparata društvene normalizacije. Izravan uvid u taj proces pružaju pak radovi nekih naših istaknutih devetnaestostoljetnih psihijatara. Prije svih to su dr. Ivo Žirovčić, dugogodišnji ravnatelj Zavoda za umobolne u Stenjevcu i dr. Dragutin Forenbacher, liječnik u Zavodu. Njihove psihijatrijsko-forenzičke rasprave potvrđuju tezu da "na temelju oblikovanja figure degenerika, smještene na stablo hereditarnosti i obremenjene stanjem koje nije stanje bolesti, nego stanje abnormalnosti (...) degeneracija omogućuje psihijatriji da funkcionira (...)" ${ }^{122}$ U njihovim je brojnim radovima posve razvidno da "degeneriranost omogućuje veliki poticaj psihijatrijskoj moći". Tako je i u prvim koracima hrvatske moderne psihijatrije "degeneracija najvažniji teorijski element medikalizacije nenormalnog". ${ }^{123}$

\section{Zaključak}

Iz Krpanova se dosjea može zaključiti da je njegovu dijagnozu postavio i konačno mišljenje sastavio jedan od naših prvih degenerativista dr. Dragutin Forenbacher, $\mathrm{u}$ to vrijeme zaposlen u Kraljevskom zemaljskom zavodu za umobolne u Stenjevcu. U njegovu Mnienju stoji da Krpan s jedne strane od djetinjstva "gaji progonstvene misli", a s druge strane da "gaji misli precjenjivanja svoje osobe". Prišivši Krpanu maniju proganjanja i egomaniju, Forenbacher zaključuje da "ovakvi ljudi osjećaju se već od svoje mladosti pozvanima da postanu nešto velikoga. Najprije promatraju narav i odnošaje ljudske, uče i čitaju vrlo mnogo, postaju nezadovoljni (...)". ${ }^{124}$ Zatim utvrđuje

\footnotetext{
${ }^{121}$ Kohout, "Higijena društva (Eugenia)”, 12: 608-609.

${ }^{122}$ Foucault, Les anormaux, 298.

${ }^{123}$ Isto.

${ }^{124}$ AKPV: MK.
} 
i nasljednu patološku crtu te složenu situaciju u obitelji. Dakle, u anamnezi, umjesto bolesti i njezine somatizacije, naglasak je na čitanju djetinjstva i primjeni teorije hereditarnosti. Medicinsko-pravni diskurs ne poseže za znanstvenim objašnjenjem, nego na samu pojavu doslovno lijepi etikete poput: stanja, djetinjstva, nagona, nasljeđa. Također, Krpana ne proglašava posve ludim: "nećemo ustvrditi da je on luđak kako si ga obično lajci predstavljaju", ali zato u više navrata naglašava njegov "duševni abnormitet". ${ }^{125}$ Kategorija nenormalnosti postaje glavnim objektom medicinsko-pravnog diskursa. Na koncu se kao glavni uzrok Krpanove paranoje navodi činjenica da je odmalena čitao filozofske i znanstvene knjige, da je uviđao nepremostiv jaz između bogatih i siromašnih, da pokazuje neodoljiv nagon za čitanjem, pisanjem i za putovanjem u inozemstvo, da mu je cilj života poboljšanje stanja cijelog čovječanstva, da prezire Crkvu, činovnike i državnu vlast. Nakon citiranja Krpanovih spisa u kojima se manje-više zastupaju opće ideje pravednosti, psihijatar zaključuje: "U ovih njekoliko redaka sadržan je cieli credo Krpanove duše, a za psychiatre sva kriterija za dokaz originarne paranoje. (...) Krpan boluje od kroničkog ludila, a da nasljed toga i kao pristaša socijalističkih načela nije sposoban za izvršavanje učiteljske službe". ${ }^{126}$ Očito je da se iz nepouzdanih analiza Krpanova karaktera izvode dalekosežni medicinski i pravni zaključci. Slučaj dakle pokazuje kako sasvim male pogreške, poput građanskog neposluha ili solidarnosti s marginaliziranima, devetnaestostoljetna psihijatrija privodi kategoriji nenormalnosti ne bi li ukrotila neposlušno tijelo, društvo očistila od prijetećih degenerativnih pojava i naposljetku dresirala pobunjeni duh.

U počecima institucionalne i znanstvene uspostave, psihijatrija u Banskoj Hrvatskoj za predmet ekspertize uzima, između ostalog, i otpor društvenom poretku i vlasti. Povezujući se s onodobnim degenerativističkim i kriminalističkim teorijama, parazitirajući na strahu od društvenog propadanja i širenja kulturno uvjetovanih anomalija, različite vidove neposluha smješta u Zavod, ondje ih ispituje, obrađuje, svladava, disciplinira i medikalizira te ih etiketira mutnom kategorijom nenormalnosti. Na taj način sebi priskrbljuje znanstveni legitimitet, a društvenu moć stječe oblikujući tehnike za suzbijanje opće opasnosti od poremećenog, patološkog i devijantnog. Sigurnost i čistoća društva u temelju su ranog psihijatrijskog djelovanja, a povezivanjem sa sudskom praksom ono postaje i nositelj pravne moći. Stenjevečki Zavod, taj hram čovječnosti, kako stoji na ploči u ulaznoj veži, osim što je nastojao biti mjestom liječenja ludih i mahnitih, bio je i mehanizmom društvene discipline i normalizacije različitih vidova ilegalnog i iregularnog ponašnja. U osnovi on je služio kao biopolitički aparat kojim su neki oblici života, tek u manjoj mjeri

\footnotetext{
125 Isto.

126 Isto.
} 
nenormirani i ne nužno bolesni (no svakako obilježeni kao poremećeni), podvrgnuti tehnikama discipline. Psihijatrijska moć, seleći se iz ludnice u škole, bolnice i tvornice, strateški je korištena u težnjama da se ukupno stanovništvo što učinkovitije organizira, nadgleda, razmjesti i iskoristi. U tom je pogledu nedvojbeno njezino poticanje i osnaživanje započetih procesa guvernmentalizacije ukupne populacije. Težnja da se Miloša Krpana, rođenog socijalista i anarhista, preobrati u rođenog kriminalca, riječju degenerika, ne bi li se njegovim duševnim abnormitetom svrhovito upravljalo, daje poprilično dobru sliku funkcioniranja psihijatrijskog diskursa i institucije Zavoda u složenom procesu oblikovanja hrvatske građanske kulture kao zdrave etničke zajednice normalnih pojedinaca. 


\section{Slikovni prilozi}

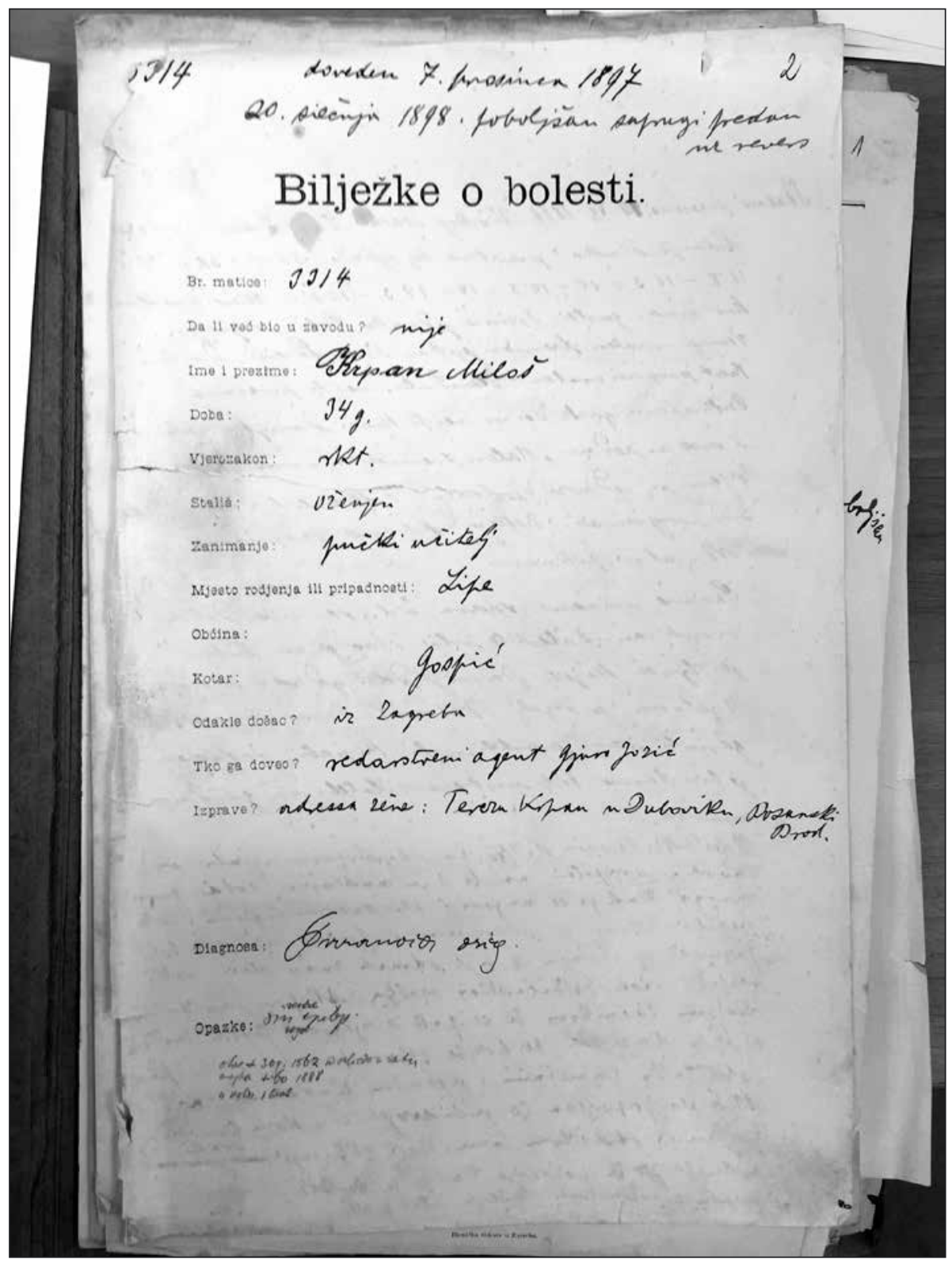

1) Početna stranica Krpanove povijesti bolesti nakon prvog primitka u Zavod 


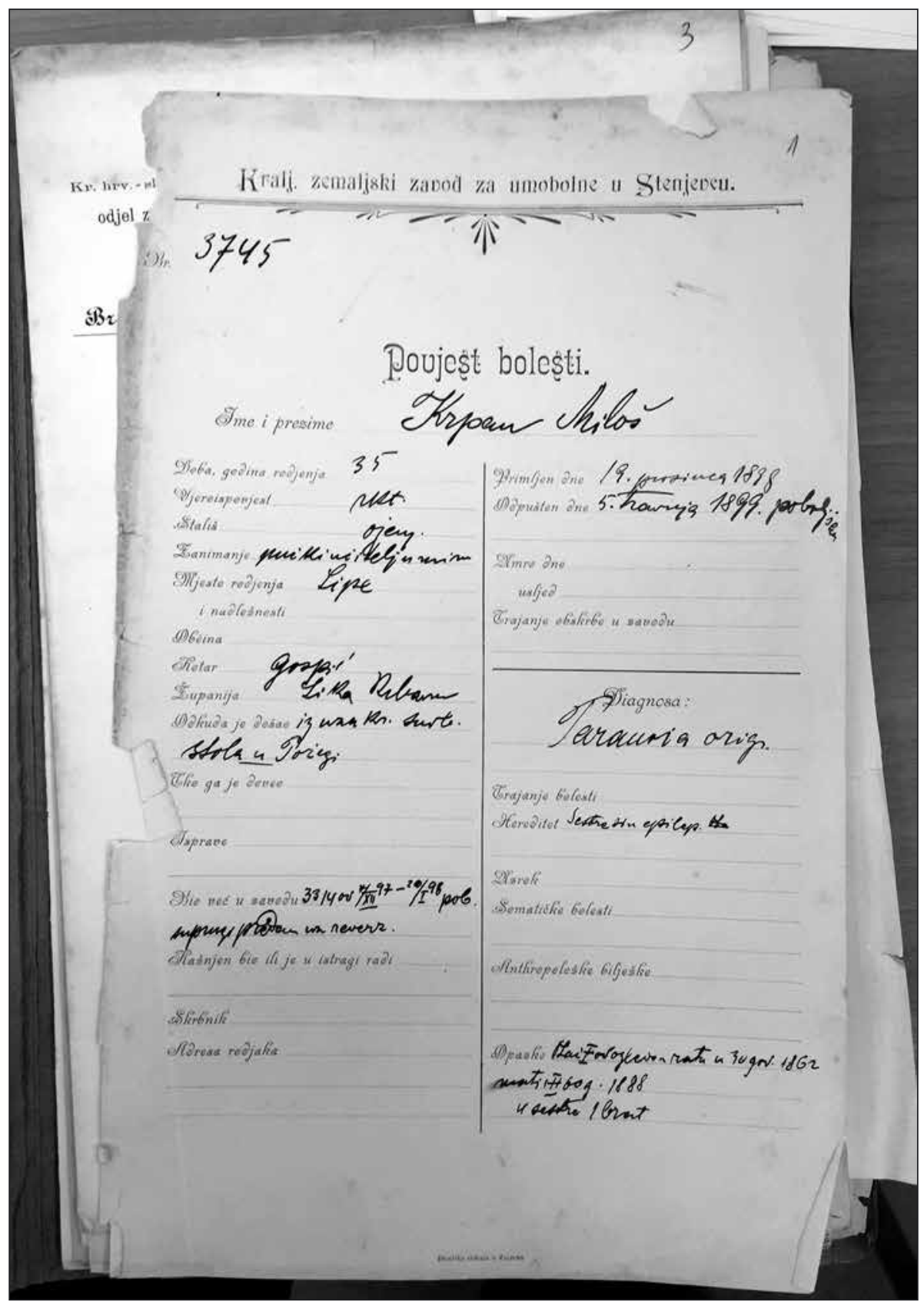

2) Početna stranica Krpanove povijesti bolesti nakon drugog primitka u Zavod 


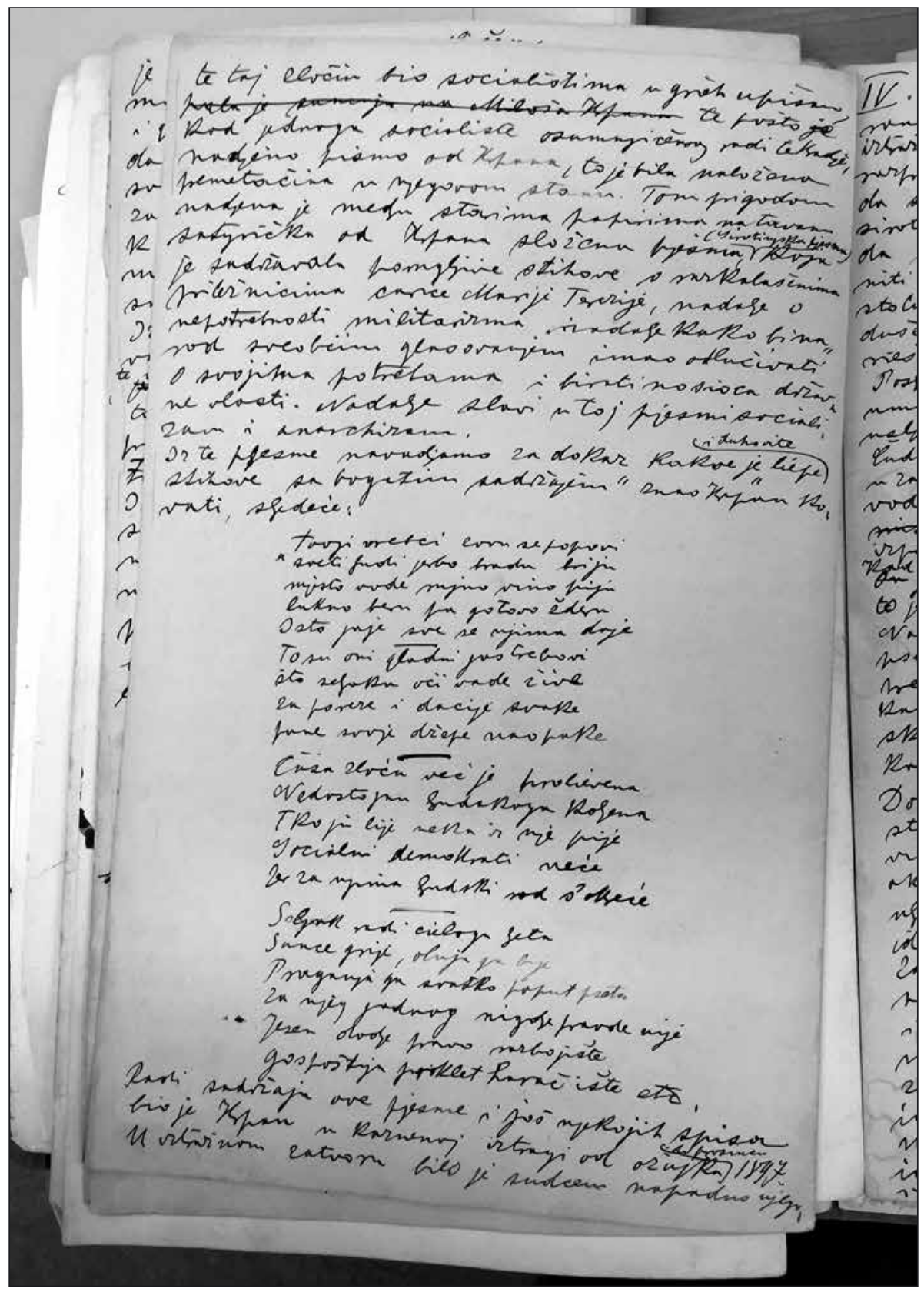

3) Stranica Krpanova dosjea na kojoj se nalazi prijepis "Sirotinjske pjesme”, zbog koje je, između ostaloga, bio priveden i optužen 


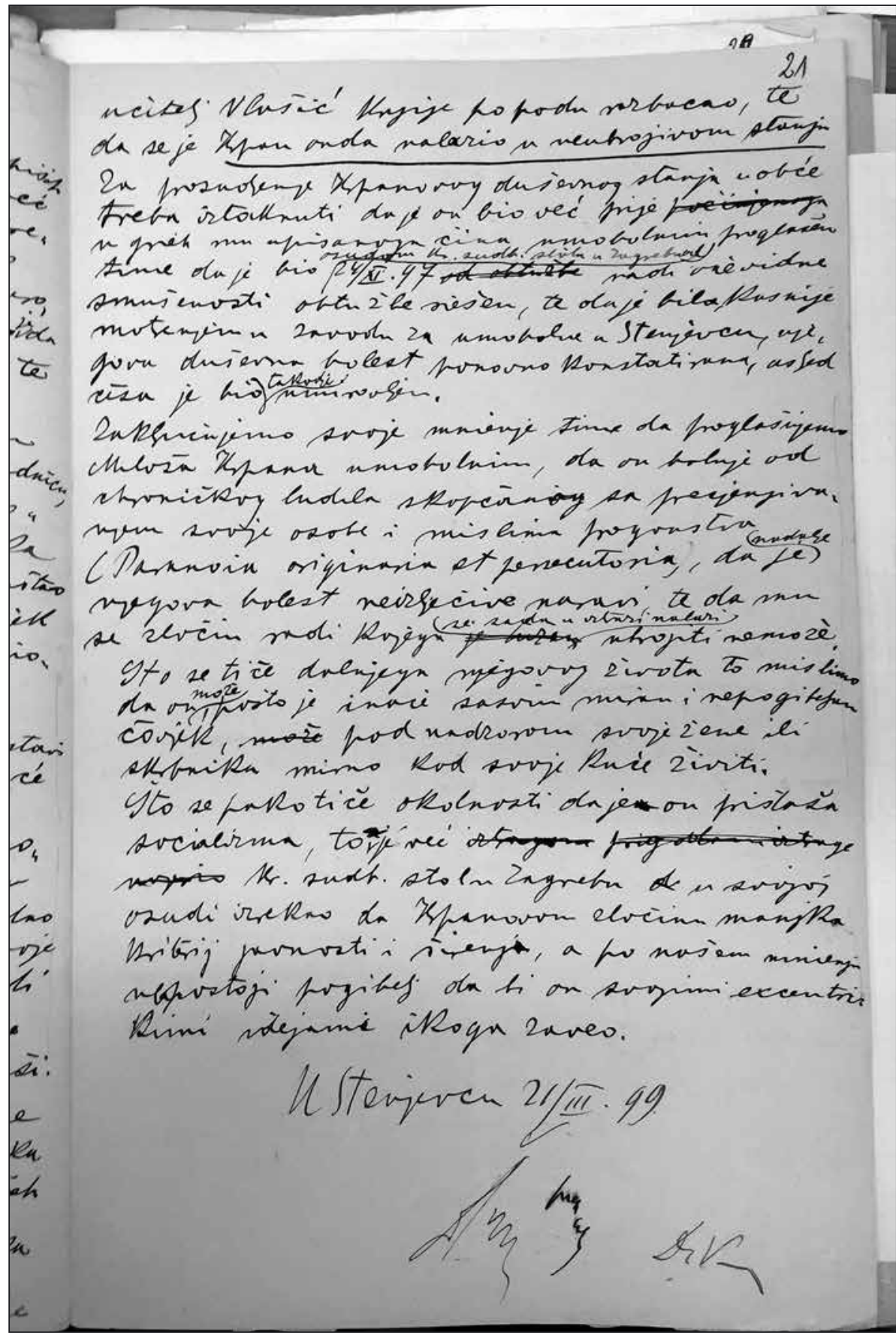

4) Stranica Krpanova dosjea na kojoj se nalazi konačno mišljenje psihijatara o njegovu duševnom stanju 


\section{Izvori}

Arhiv Klinke za psihijatriju "Vrapče”, Miloš Krpan, Bilježke o bolesti nastale između 7. prosinca 1897. i 20. siječnja 1898. Redni broj zaprimanja pacijenta 3314; Miloš Krpan, Povjest bolesti nastala između 19. prosinca 1898. i 5. travnja 1899. Redni broj zaprimanja pacijenta 3745 .

Kazneni zakon o zločinstvih, prestupcih i prekršajih od 27. svibnja 1852. sa zakoni $i$ naredbami i sa rješidbami. Zakon o porabi tiska od 17. svibnja 1875., izpravljen prema zakonu od 14. svibnja 1907. o promjeni tiskovnih zakona. Ur. Josip Šilović. Zagreb: St. Kugli, Knjižara Kraljevskog Sveučilišta i Jugoslavenske akademije, 1908.

“Godišnje izviešće kr. zemaljskog zavoda za umobolne u Stenjevcu za god. 1880", Liečnički viestnik, 1881 (5), br. 3: 43.

"Liečničko izvješće”, Liečnički viestnik, 1883 (6), br. 7: 99-102.

"Liečničko izvješće kralj. zemalj. zavoda za umobolne u stenjevcu, za god. 1885. od Dra. Ivana Rohačeka, ravnatelja toga zavoda”, Liečnički viestnik, 1886 (8), br 11: 171-182.

"Godišnje izvješće kr. zemalj. zavoda za umobolne u Stenjevcu za god. 1886. od Dra. Ivana Rohačeka, ravnatelja zem. zavoda za umobolne", Liečnički viestnik, 1887 (9), br. 5: 65-73.

"Levico", Liečnički viestnik, 1888 (10), br. 6: 95.

“Sitne viesti”, Liečnički viestnik, 1897 (19), br. 8: 287288.

Osnova za građenje ludnice u Zagrebu. Hrvatski državni arhiv, UOZV, 79/115/18/11958.

\section{Literatura}

Bradshow, David. "Eugenics: They should certainly be killed", u: A Concise Companion to Modernism, uredio David Bradshow, Malden: Bleckwell, 2005., 34-55.

Dedić, Dejan. "Prilog biografiji Miloša Krpana", u: Miloš Krpan. Izabrani spisi, uredio Dejan Dedić, Zagreb: DAF, 2010., 247-255.

Foucault, Michel. Istorija seksualnosti. Volja za znanjem. Beograd: Prosveta, 1982.

Foucault, Michel. Nadzor i kazna. Zagreb: Informator-Fakultet političkih znanosti, 1994.

Foucault, Michel. Znanje i moć. Zagreb: Globus, 1994.

Foucault, Michel. "The Ethics of Care for the Self as the Practice of Freedom", u: The Final Foucault, uredili J. W.Bernauer i D. Rasmussen, Cambridge: MIT Press, 1994., 1-20.

Foucault, Michel. Les anormaux. Paris: Gallimard-Le Seuil, 1999.

Foucault, Michel. Psychiatric Power. New York: Palgrave Macmillian, 2006.

Foucault, Michel. Security, Territory, Population. New York: Palgrave Macmillian, 2009. 
Foucault, Michel. Rođenje biopolitike. Zagreb: Sandorf - Mizantrop, 2016.

Galton, Francis. Inquiries into Human Faculty and its Development. London-New York: Dent and Dutton, 1907.

Glesinger, Lavoslav. "Povijest psihijatrije u Hrvatskoj”, u: Ludnica i lučbarnica, uredili Marko Pećina i Stella Fatović-Ferenčić, Zagreb: HAZU, 2012., 18-88.

Gross, Mirjana; Szabo, Agneza. Prema hrvatskome građanskom društvu. Društveni razvoj u civilnoj Hrvatskoj i Slavoniji šezdesetih i sedamdesetih godina 19. stoljeća. Zagreb: Globus, 1992.

Herceg, Rudolf, “Zavod za umobolne 'Stenjevec' od 1879. do 1933”, u: Stenjevec, državna bolnica za duševne bolesti 1879-1933, Zagreb: Društvo za socijalnu pomoć duševnim bolesnicima u Stenjevcu, 1933., 6-29.

Hobsbawm, Eric. Doba kapitala. Zagreb: Školska knjiga, 1989.

Iveljić, Iskra. Očevi i sinovi. Privredna elita Zagreba u drugoj polovici 19. stoljeća. Zagreb: Leykam international, 2007.

Kohout, Bogomil. “Degeneracija čovječeg pokoljenja”, Liečnički viestnik, 1907 (29), br. 4: 98-104.

Kohout, Bogomil. “Degeneracija čovječeg pokoljenja”, Liečnički viestnik, 1907 (29), br. 5: 133-139.

Kohout, Bogomil. "Higijena društva (Eugenia)”, Liečnički viestnik, 1913 (33), br. 11: 546-553.

Kohout, Bogomil. "Higijena društva (Eugenia)”, Liečnički viestnik, 1913 (33), br. 12: 604-610.

Kovačević, Ivan. "Pokušaj osnivanja anarhističko-komunističke kolonije u Duboviku kraj Slavonskog Broda (1909. i 1910.)", u: Miloš Krpan. Izabrani spisi, uredio Dejan Dedić, Zagreb: DAF, 2010., 240-246.

Krpan, Miloš. Izabrani spisi, uredio Dejan Dedić. Zagreb: DAF, 2010.

Kuhar, Martin. Eugenika u hrvatskoj medicini i njezin utjecaj na javnost u razdoblju od 1859. do 1945., doktorska disertacija, 2015. http://medlib.mef.hr/2226/1/ Kuhar_M_disertacija_rep_2226.pdf (pristup ostvaren 10. I. 2020).

Luetić, Tihana. Studenti Sveučilišta u Zagrebu (1874-1914). Društveni život, svakodnevica, kultura, politika. Zagreb: Srednja Europa, 2012.

Matoš, Antun Gustav. "Kult energije”, u: Sabrana djela. Feljtoni, impresije, članci II. Sv. XVI, uredila Vida Flaker, Zagreb: Mladost, 1973., 102-106.

Matoš, Antun Gustav. Sabrana djela. O hrvatskoj književnosti II. Sv. VII. Zagreb: Mladost, 1973.

Oosterhuis, Harry. Stepchildren of nature. Krafft-Ebing, Psychiatry, and the Making of Sexual Identity. Chicago-London: The University of Chicago Press, 2000.

Pastović, Dunja i Željko, Darija, "Zakonodavni okvir uređenja prostitucije na hrvatsko-slavonskom području 1852. - 1929.”, Pravni vjesnik: časopis za pravne $i$ društvene znanosti Pravnog fakulteta Sveučilišta J. J. Strossmayera u Osijeku 1 (2016): 29-53. 
Pejić, Luka. "Kriminal i represivni sustav u Osijeku na prijelazu iz 19. u 20. stoljeće promatran kroz elemente biopolitike i socijalne povijesti”. Scrinia Slavonica 15 (2015): 133-174.

Pejić, Luka, “Odnos radničkog pokreta i seljaštva na prijelazu iz 19. u 20. stoljeće u Osijeku i okolici“. Historijski zbornik 2 (2018): 411-438.

Pejić, Luka, "Godine revolta: Štrajkovi radnika slavonske drvnoprerađivačke industrije (1905. - 1907.)", u: Slavonske šume kroz povijest. Zbornik radova znanstvenog skupa s međunarodnim sudjelovanjem održanog u Slavonskom Brodu 1.-2. listopada 2015., uredili Dinko Župan i Robert Skenderović, 327-357. Slavonski Brod: Hrvatski institut za povijest - Podružnica za povijest Slavonije, Srijema i Baranje, 2018.

Petković, Krešimir. Istina kao kušnja. Zagreb: Plejada, 2018.

Predragović, Miljenko. "Da li se naš Miloš Krpan dopisivao s Engelsom?“. Vjesnik, 11. lipnja 1972.

Rabinbach, Anson. "Mental Fatigue, Neurastenia, and Civilization", u: Human Motor: Energy, Fatigue, and the Origins of Modernity, Berkeley-Los Angeles: University of California Press, 1992., 146-178.

Rajković, Ana. "Počeci kreiranja anarhističkog narativa u kontekstu slavonskog radničkog pokreta (1881-1914)". Historijski zbornik 1 (2018): 61-86.

Sharpe, Andrew N. Foucault's Monsters and the Challenge of Law. London-New York: Routledge, 2011.

Tissot, Samuel Auguste Andre David. Von der Onanie oder Abhandlung über die Krankheiten die von der Selbstbesleckung herrühren. Zagreb: Joh. Thom. Edlen von Trattnern, 1794.

Župan, Dinko. “Odnos prema tijelu unutar hrvatskog školskog sustava druge polovine 19. stoljeća”, Radovi Zavoda za hrvatsku povijest 40 (2008): 189-209.

Župan, Dinko. Mentalni korzet. Spolna politika obrazovanja žena u Banskoj Hrvatskoj (1868-1918). Osijek-Slavonski Brod: Učiteljski fakultet u Osijeku-Hrvatski institut za povijest, 2013.

Wessely, Simon. "Neurastenija and Fatigue Syndromes", u: A History of Clinical Psychiatry. uredili German E. Berrios i Roy Porter, London: The Altone Press, 1995., 509-544. 


\author{
Summary \\ HUNTING DOWN THE DEGENERATES \\ Psychiatry and the Normalization of Croatian Civil Society: \\ Miloš Krpan, a case study
}

Focusing on the psychiatric case of Miloš Krpan, one of our first socialists and anarchists who was twice admitted to the Royal Institute for Mentally Insane in Stenjevec at the end of the 19th century, the paper aims to show how, by participating in the construction of Croatian civil society, psychiatry develops medical knowledge but also normalizes power. Psychiatry pacifies the resistance against the system by dislocating it to the Institute where it is further examined, processed, mastered and disciplined. At the same time, it acquires scientific legitimacy and gains social status by producing a category of the abnormal and by developing techniques to repress it. Thus, it assumes responsibility for social morale, security and purity, and by associating itself with judicial practice it becomes one of the main legal authorities. In other words, apart from seeking to cure insanity, psychiatry emerges as an apparatus of social discipline and establishes modern forms of normalizing power in the young bourgeois capitalist society of the second half of the 19th century.

Keywords: history of psychiatry, abnormality, degeneration, normalization, Miloš Krpan

\title{
Kontakt autorâ:
}

Prof. dr. sc. Mislava Bertoša

Odsjek za lingvistiku, Filozofski fakultet Sveučilišta u Zagrebu

mbertosa@ffzg.hr

Prof. dr. sc. Tvrtko Vuković

Odsjek za kroatistiku, Filozofski fakultet Sveučilišta u Zagrebu

tvrtkovukovic@yahoo.com 